\title{
Roles of mTOR Signaling in Tissue Regeneration
}

\author{
Xiangyong Wei, Lingfei Luo * and Jinzi Chen * \\ Laboratory of Molecular Developmental Biology, School of Life Sciences, Southwest University, Beibei, \\ Chongqing 400715, China; xiangyongwei2016@outlook.com \\ * Correspondence: lluo@swu.edu.cn (L.L.); chjz2012@email.swu.edu.cn (J.C.); \\ Tel.: +86-23-68367957 (L.L.); Fax: +86-23-68367958 (L.L.)
}

Received: 9 August 2019; Accepted: 7 September 2019; Published: 12 September 2019

\begin{abstract}
The mammalian target of rapamycin (mTOR), is a serine/threonine protein kinase and belongs to the phosphatidylinositol 3-kinase (PI3K)-related kinase (PIKK) family. mTOR interacts with other subunits to form two distinct complexes, mTORC1 and mTORC2. mTORC1 coordinates cell growth and metabolism in response to environmental input, including growth factors, amino acid, energy and stress. mTORC2 mainly controls cell survival and migration through phosphorylating glucocorticoid-regulated kinase (SGK), protein kinase B (Akt), and protein kinase C (PKC) kinase families. The dysregulation of mTOR is involved in human diseases including cancer, cardiovascular diseases, neurodegenerative diseases, and epilepsy. Tissue damage caused by trauma, diseases or aging disrupt the tissue functions. Tissue regeneration after injuries is of significance for recovering the tissue homeostasis and functions. Mammals have very limited regenerative capacity in multiple tissues and organs, such as the heart and central nervous system (CNS). Thereby, understanding the mechanisms underlying tissue regeneration is crucial for tissue repair and regenerative medicine. mTOR is activated in multiple tissue injuries. In this review, we summarize the roles of mTOR signaling in tissue regeneration such as neurons, muscles, the liver and the intestine.
\end{abstract}

Keywords: mTOR signaling; metabolism; tissue regeneration; neuron; muscle; liver; intestine

\section{Introduction}

In the 1970s, a new antifungal, was discovered in soil samples on the Polynesian island of Rapa Nui, which was isolated from Streptomyces hygroscopicus and called rapamycin [1,2]. Afterwards, FK506-binding protein 12 (FKBP12) was found to repress cell growth and proliferation [3]. During the 1990s, the target of rapamycin (TOR) and the mammalian target of rapamycin (mTOR) were discovered in yeast and mammals respectively [2]. Brown et al. reported that mTOR is a target of the FKBP12-rapamycin complex [4]. mTOR is a serine/threonine protein kinase, which recruits other proteins to form two different complexes, named mTOR complex 1 (mTORC1) and complex 2 (mTORC2). mTOR is conserved in the evolution from yeast to mammal [1]. mTORC1 and mTORC2 contain the same subunits: mTOR, mammalian lethal with Sec13 protein 8 (mLST8) and DEP domain-containing mTOR-interacting protein (DEPTOR). However, regulatory-associated protein of mTOR (Raptor) and $40 \mathrm{kDa}$ proline-rich Akt substrate (PRAS40) are specific to mTORC1, while rapamycin-insensitive companion of mTOR (Rictor), Protor $1 / 2$ and mammalian stress-activated protein kinase(SAPK)-interacting protein $1(\mathrm{mSin} 1)$ are specific to mTORC2 [1,5]. mTOR signaling plays crucial roles in the regulation of cell growth, metabolism, cell survival and migration. In response to growth factors, energy, amino acid, and oxygen, mTORC1 controls cell growth and metabolism through mRNA translation, synthesis of protein, lipid and nucleotide, and repression of catabolic processes such as autophagy [6]. The ribosomal S6 kinase (S6K) and eIF4E-binding protein 1 (4EBP1) are the main effectors of mTORC1. Unlike mTORC1, studies on mTORC2 are limited. mTORC2 mainly controls cell 
survival and migration through phosphorylation and activation of the downstream-effectors SGK1, Akt, and the PKC kinase families [5]. The mTORC2 is an effector of the insulin/PI3K pathway and is a key regulator of Akt [5,7]. mTOR signaling is the central pathway in response to the environment, and the disruption of mTOR signaling is associated with developmental defects, cancer, neurodegenerative diseases, type 2 diabetes, autoimmune diseases, and aging-related diseases [8-12]. Thus, mTOR is therefore a therapeutic target of these diseases [13].

Tissue damage caused by trauma, diseases, and aging, etc. can result in organ dysfunction. Afterward, tissue regeneration is critical for the restoration of organ functions and maintenance of homeostasis [14]. In adult humans, although the regenerative capacity of some organs, like the central nervous system (CNS) and heart, is weak, other organs, including the liver, intestines, muscles, and skin, do maintain the intrinsic ability to regenerate [15]. The key reasons why different organs obtain distinct regenerative capacities and different species obtain distinct regenerative capacities in the same organ remain to be elucidated. So, mechanistic insights into tissue regeneration are essential for tissue repair and regenerative medicine [14]. mTOR is one of the central regulatory signaling pathways between injuries and physiological reactions such as tissue regeneration. For example, in the CNS with very weak regenerative capacity, activated mTOR through the inactivation of PTEN (phosphatase and tensin homolog) or TSC1 (tuberous sclerosis complex 1) can robustly promote axonal regeneration [16]. mTOR is also vital in the regeneration of the intestines, liver and muscles.

In this review, we first briefly describe the structures, regulatory mechanisms, and physiological functions of mTORC1 and mTORC2. Then, we put our efforts toward summarizing the roles of mTOR signaling in the regeneration of neurons, muscles, the liver, and intestine. At the end, the development strategy of tissue-specific agonist or inhibitor of mTORC1 in regenerative medicine is discussed.

\section{The Structure and Regulation of mTORC1}

mTOR is a serine/threonine protein kinase and a member of the PI3K-related kinase (PIKK) family, which forms the mTORC1 and mTORC2 complexes with other proteins $[17,18]$. The mTORC1, a heterotrimeric protein kinase, is mainly composed of three core components including mTOR, Raptor, and mLST8 [19-22]. mTORC1 also contains two inhibitory subunits, PRAS40 and DEPTOR [23-25]. After acute rapamycin treatment, the FKBP12-rapamycin complex binds to the FKBP12-rapamycin-binding (FRB) domain of mTOR and blocks mTORC1 activation [26] (Figure 1A). The mTORC1 plays important roles in metabolism and cell growth in response to nutrients and is regulated by many factors including growth factors, amino acids, energy, oxygen, and DNA damage [1,27]. Insulin/insulin-like growth factors (IGFs) inhibit the TSC complex, an inhibitory heterotrimeric complex of mTOR containing TSC1, TSC2, and Tre2-Bub2-Cdc16 (TBC) 1 domain family, member 7 (TBC1D7) [28], thus activating mTORC1. This mTORC1 activation is dependent on the Akt-mediated phosphorylation of TSC, which dissociates TSC from the lysosomal membrane [29]. The Ras signaling activates mTORC1 through extracellular signal-regulated kinase (Erk) and p90RSK, both of which phosphorylate and inhibit TSC2 [30] (Figure 1A). It is worth mentioning that Ras homolog enriched in brain (Rheb) is indispensable for mTORC1 activation. Some papers reported that Rheb activates mTORC1 through interruption of the FKBP38-mTOR interaction or directly binding to mTOR [31,32], however, the detailed mechanisms underlying activation of mTORC1 by Rheb remain to be fully elucidated. 

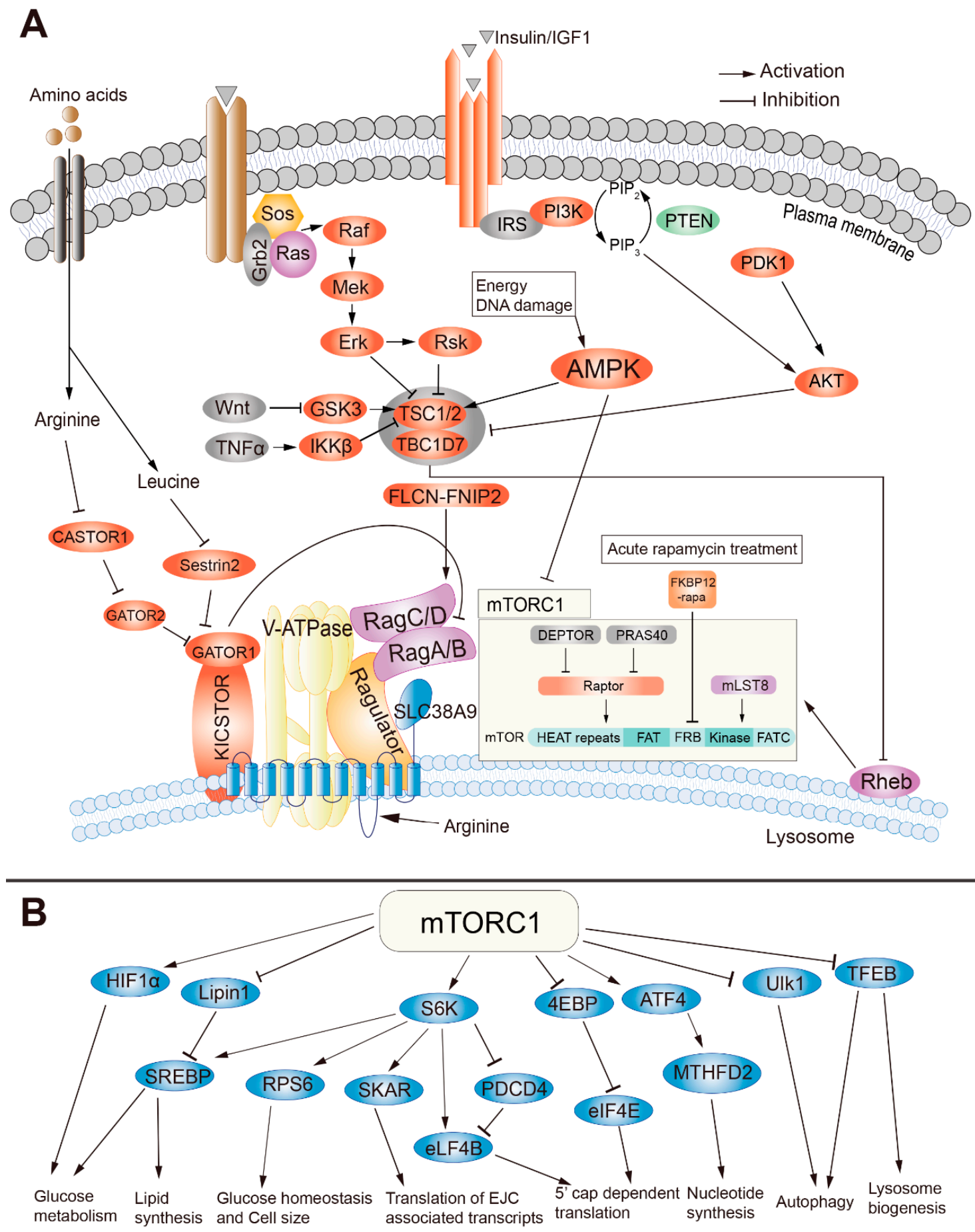

Figure 1. The regulatory mechanism and function of the mammalian target of rapamycin complex 1 (mTORC1). (A) The structures and regulatory mechanism of mTORC1. (B) The downstream functions of mTORC1.

The mTORC1 activation is closely related to the variation of amino acid concentrations. Different types of amino acid stimulate mTORC1 through different sensors. For example, cytosolic leucine, cytosolic arginine, and the lysosomal arginine are sensed by Sestrin2, CASTOR1 (Cellular Arginine Sensor for mTORC1) complex, and a candidate lysosomal amino acid sensor SLC38A9, respectively [1,33-36]. Amino acids activate mTORC1 through an amino acid sensing cascade involving the vacuolar $\mathrm{H}^{+}$-ATPase (v-ATPase), RAG GTPases (small guanosine triphosphatases) and Ragulator. Unlike other stimulators, mTORC1 activation by amino acids is independent of the TSC-Rheb signaling 
axis [37] (Figure 1A). In contrast to leucine and arginine, glutamine also promotes mTORC1 activation, which is dependent on the related Arf family GTPases rather than Rag GTPase [38]. Folliculin-FNIP2 (folliculin interacting protein 2) complex, a Rag-interacting protein with GAP (GTPase-activating protein) activity for $\mathrm{RagC} / \mathrm{D}$, was recently reported to activate $\mathrm{mTORC} 1$ in the existence of amino acids $[36,39]$. Except cytosolic arginine, leucine and lysosomal arginine, whether other amino acids activate mTORC1, and the identity of their sensors remains unknown. Furthermore, energy, oxygen, and DNA damage negatively regulate mTORC1 through AMPK (5' AMP-activated kinase), which indirectly inhibits mTORC1 activation via phosphorylation of TSC2 or direct phosphorylation of Raptor [40-42]. Moreover, both wingless-type MMTV integration site family (Wnt) signaling and tumor necrosis factor $\alpha(\mathrm{TNF} \alpha)$ activate mTORC1 through inhibition of TSC1 $[43,44]$.

The activated mTORC1 enhances protein synthesis through direct phosphorylation of the ribosomal S6 kinase (S6K) and 4E-BP1 [45]. Then, the phosphorylated S6K (pS6K) promotes mRNA translation initiation through phosphorylation and activation of eIF4B, a positive regulator of the $5^{\prime}$ cap-binding eIF4F complex, and promotion of the degradation of PDCD4 (programmed cell death protein 4), an inhibitor of elF4B [46,47]. pS6K also regulates glucose homeostasis and cell size through phosphorylation of ribosomal protein s6 (rps6) [48]. Moreover, the interaction of pS6K and SKAR (S6K1 Aly/REF-like substrate) improves the translation efficiency of spliced mRNAs [49]. The phosphorylated 4E-BP1 dissociates its binding to eIF4E, which allows eIF4E to join in the eIF4F complex together with eIF4G, thus permitting the cap-dependent translation [50]. All the regulations above finally promote protein synthesis. The mTORC1-dependent anabolism is mediated by phosphorylation of S6K, inhibition of lipin1, an inhibitor of lipid synthesis, [51] and activation of ATF4 (activating transcription factor 4), a promoter of nucleotide synthesis [52]. mTORC1 also augments the glycolytic pathway through increasing the translation of hypoxia inducible factor $1 \alpha(\mathrm{HIF} \alpha)$, which drives the expression of phospho-fructo kinase (PFK) [53]. Furthermore, mTORC1 suppresses the catabolism such as autophagy and lysosome biogenesis through phosphorylation of ULK1 (unc-51 like autophagy activating kinase 1) and the transcription factor EB (TFEB) [54,55] (Figure 1B). In conclusion, mTORC1 regulates cell growth and metabolism in response to environmental inputs such as growth factors, nutrients, and DNA damage. It plays significant roles in development, physiological processes, and diseases.

\section{The Structure and Regulation of mTORC2}

Like mTORC1, mTORC2 also contains mTOR and mLST8 subunits. But Raptor in mTORC1 is replaced by Rictor in mTORC2 [56]. mTORC2 also includes DEPTOR, the regulatory subunits mSin 1 and Protor1/2 [25,57,58]. mTORC2 can be impeded by prolonged rapamycin treatment [59]. Unlike mTORC1, the upstream and downstream activity of mTORC2 are not well-defined. mTORC2, as an effector of insulin/PI3K signaling, is inhibited by the pleckstrin homology domain of mSin1 when there is a lack of insulin. This autoinhibition by $\mathrm{mSin} 1$ is relieved upon its binding to phosphatidylinositol $(3,4,5)$-trisphosphate (PIP3) on the plasma membrane [7]. Akt activates mTORC2 through phosphorylation of mSin1 at T86, in turn the activated mTORC2 stimulates Akt through phosphorylation of Akt at S473, which forms a positive feedback regulatory loop [5,60]. In contrast to Akt, S6K suppresses mTORC2 via promoting the degradation of insulin receptor substrate 1 (IRS1) [61].

The mTORC2 mainly controls cell migration through phosphorylation of the AGC (protein kinase A/G/C) protein kinase family members such as PKC $\alpha$ [56], PKC $\delta$ [62], PKC [63], PKC $\gamma$ and PKC $\varepsilon$ [64], all of which regulate cell migration through modulations of various aspects of cytoskeletal remodeling. Furthermore, another important function of $\mathrm{mTORC} 2$ is phosphorylation and activation of Akt, which in turn phosphorylates and inhibits forkhead box O1/3a (FoxO1/3a), TSC2 and the metabolic regulator glycogen synthase kinase $3 \beta$ (GSK3 $\beta)[65,66]$, thus promoting cell survival and proliferation. In addition, mTORC2 can phosphorylate and activate SGK1, which regulates ion transport for cell survival [67] (Figure 2). mTORC2 is also involved in cancer, Alzheimer's disease (AD) [10,68]. 


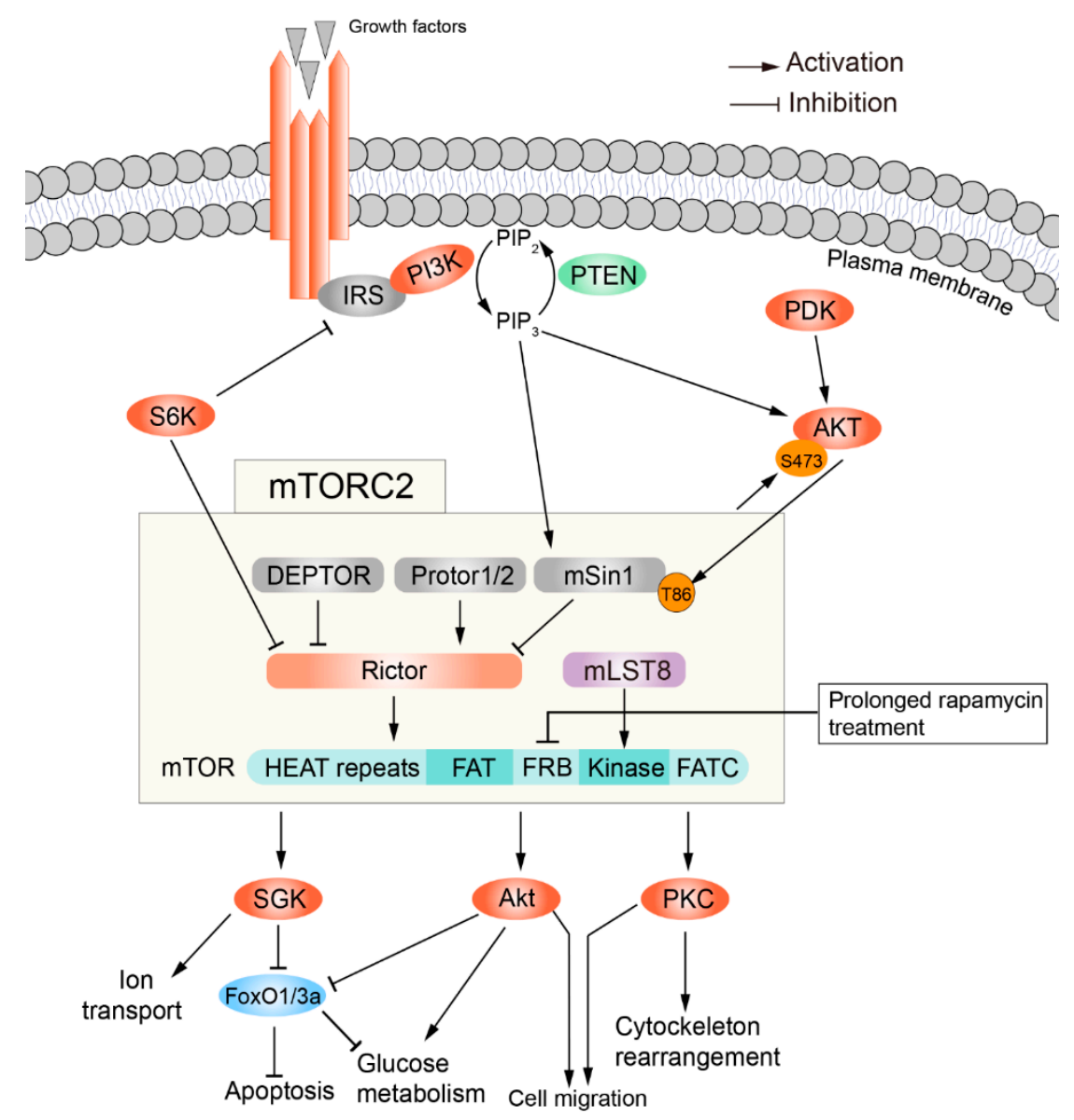

Figure 2. The structures, regulatory mechanism and functions of mTORC2.

\section{Roles of mTOR in Neuronal Regeneration}

The blood-brain barrier (BBB) is formed by endothelial cells, pericytes and astrocytes. These cells together form the neurovascular unit (NVU), which serves as an interface between the blood and the neural tissue. Impairment of BBB function is associated with neurodegenerative diseases [69]. The brain endothelial cells are vital for the function of BBB [70]. Brain vascular damage or occlusion can cause cerebrovascular diseases such as microbleeding, hemorrhagic stroke, and ischemic stroke. Macrophages and lymphatic vessels are important for the repair of brain blood vessels and the restoration of BBB functions [71,72]. The nervous system is comprised of the central nervous system (CNS) and peripheral nervous system (PNS) [73]. The PNS has a unique ability to regenerate [74-76]. However, the CNS of adult mammals including the brain and spinal cord obtains very limited regenerative capacity, which might partially result from abundant inhibitory growth factors in the CNS [77-80]. Effective therapeutic approaches are still missing for a wide variety of human neurodegenerative diseases including Parkinson's disease (PD), amyotrophic lateral sclerosis (ALS), Huntington's disease (HD), and Alzheimer's disease (AD) [81-86]. Therefore, the neuronal regeneration of the CNS of adult mammals constantly remains an important research topic, being of great significance for clinical treatment.

In general, axons after injury do not spontaneously regenerate in adult mammalian CNS because of a diminished intrinsic regenerative capacity and extrinsic growth-inhibitory factors $[77,87,88]$. Inhibitory factors from myelin including Nogo protein families, Oligodendrocyte myelin glycoprotein (OMgp), myelin-associated glycoprotein (Mag), ephrin B3, and transmembrane semaphorin 4D (Sema4D/CD100) block CNS axonal regrowth $[79,89,90]$. Chondroitin sulphate proteoglycans (CSPGs) produced by the reactive astrocytes in the glial scar become main inhibitory extracellular matrix (ECM) molecules at the lesion site of a mature CNS [90,91]. Therefore, both promotion of the intrinsic 
regenerative capacity and suppression of the inhibitory environment are required for efficient axon regeneration [77,92]. Either overexpression of osteopontin, IGF1 and ciliary neurotrophic factor (CNTF), or genetic inactivation of PTEN, a negative regulator of mTOR signaling, TSC1/2 and suppressor of cytokine signaling 3 (SOCS3), can promote axon regeneration. Signaling pathways like Janus kinase/signal transducers and activators of transcription (JAK/STAT3), canonical bone morphogenetic protein/drosophila mothers against decapentaplegic (BMP/Smad), non-canonical BMP pathway, Jun N-terminal kinase/p38 MAP kinase (JNK/MAPK), and mTOR signaling, have been reported to promote axonal regrowth during neuronal regeneration [16,93-95]. Here, we summarize the roles of mTOR in axonal regeneration of the CNS and PNS.

Injuries to the optic nerves and spinal cord have been widely used to study axonal regeneration of the CNS. mTOR signaling exhibits distinct functions in the optic nerve and spinal cord regeneration [76]. mTOR signaling is highly activated at the embryonic stage and diminished in the adult retinal ganglion cells (RGCs), suggesting the different functions at various developmental stages of RGCs. Activation of mTOR via genetic deletion of TSC1 or PTEN enhances axonal regeneration of RGCs after optic nerve injury [16]. Similarly, axon regeneration robustly occurs when PTEN is deficient in mouse cortical motor neurons [96], Drosophila sensory neurons [97], and Caenorhabditis elegans motor neurons [98]. The melanopsin/GPCR (cell-type-specific G protein-coupled receptor) signaling enhances axonal regeneration of RGCs through promotion of mTORC1 signaling. Interestingly, the regenerative activation is in a light-dependent manner [99]. Class I histone deacetylation enzyme HDACs that allow histones to wrap DNA more tightly, has been shown to repress the RGCs survival and regeneration after optic nerve injury. Dual deletions of HDAC1 and HDAC2 or HDAC3 deficiency robustly promotes RGCs regeneration $[100,101]$. Recently, dual functions of HDAC5 have been shown in the regeneration of dorsal root ganglions (DRGs) of the PNS [102,103]. Increases in the HDAC5 cytoplasmic localization by overexpressing the mutant HDAC5 $5^{\mathrm{AA}}$ can stimulate RGCs regenerative ability after optic nerve injury. This enhanced RGC regeneration is dependent on mTORC1 [104]. Another study revealed that Wnt10b from fibroblast-derived exosomes (FD exosomes) enhances neurite regrowth through regulation of GSK3 $\beta$ and TSC2 to boost mTOR activation [105]. After optic nerve injury, the mTOR is unnecessary for the initial step of RGCs to enter into the regenerative status but required for long axon regeneration under inflammatory stimulation [106]. Furthermore, the elevation of mTOR either by the overexpression of Rheb, or by double deletion of Pten and Socs3, or by Pten deletion combined with the injection of cAMP (cyclic adenosine monophosphate) analogue 4-(chlorophenylthio) adenosine (CPT)-cAMP or inflammatory molecules (oncomodulin or zymosan) can enhance RGCs growth into the brain [107-110]. The combinatory treatments after optic nerve injury are able to achieve visual functional recovery.

Although studies above suggest that mTOR signaling promotes RGC regeneration, Li et al. showed that mTOR is a negative regulator of RGCs survival and activates astrocytes after optic nerve injury. In the rat retinal ischemia-reperfusion (I/R) injury model, neuroprotective effects of rapamycin can reduce the loss of RGCs after optic nerve injury. Thus, the neuroprotective effects of rapamycin supply a therapeutic method for optic neurodegeneration [111]. Overall, activated mTOR robustly enhances RGCs regeneration after optic nerve injury and also promotes astrocyte activation to form a physical and biochemical barrier glial scar for inhibiting axonal regeneration (Figure 3A). Specific activation of mTOR in RGCs or inhibition in astrocytes after injury promotes RGC regrowth and regeneration, suggesting $\mathrm{mTOR}$ as a potential therapeutic target for optic nerve injury and neurodegenerative disease. In summary, activated mTOR enhances RGCs regeneration after optic nerve injury and also promotes astrocytes activation to form physical and biochemical barrier glial scar that could inhibit axonal regeneration (Figure 3A). 


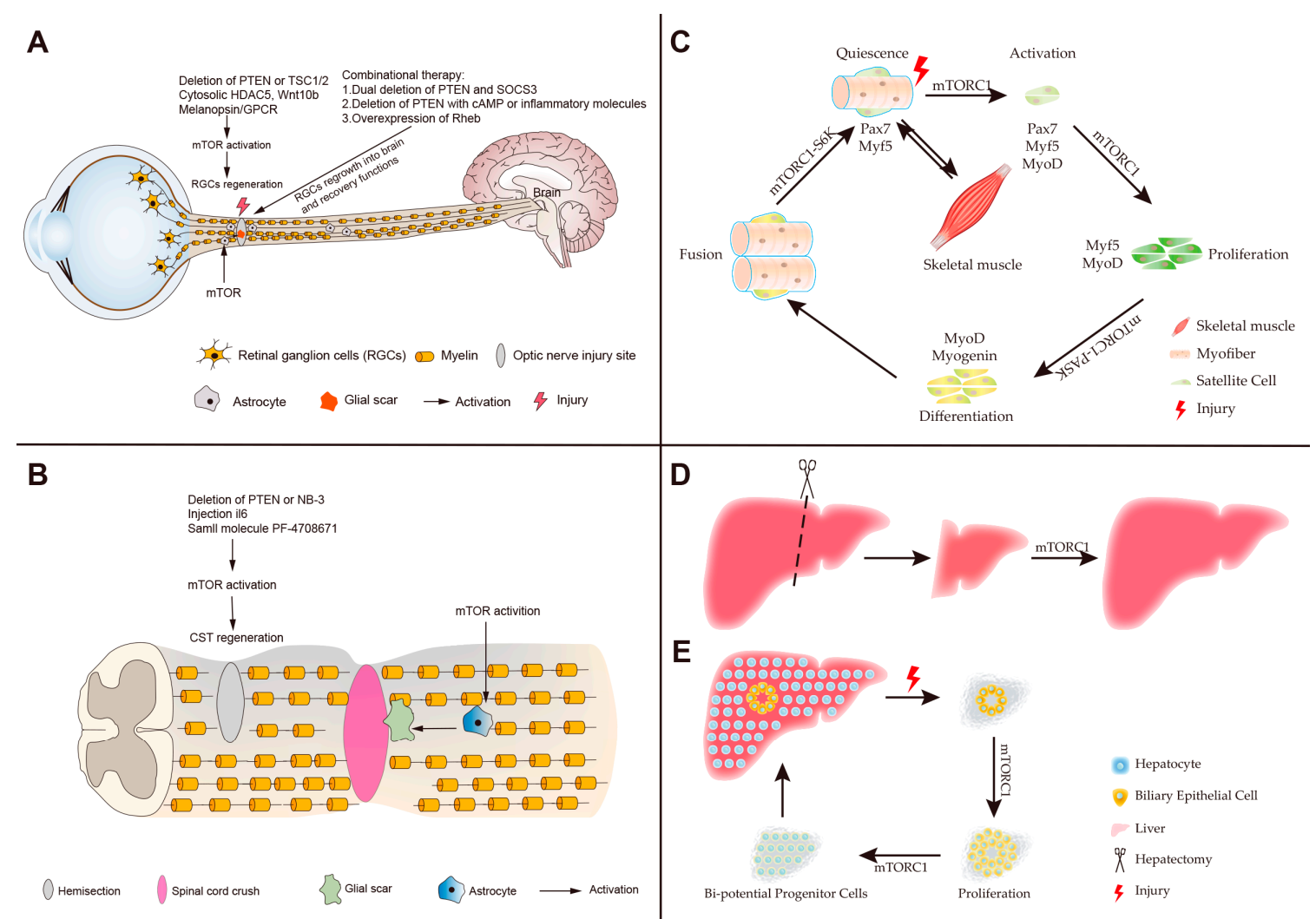

Figure 3. The roles of mTOR in the regeneration of neurons, muscles and the liver. (A) The optic nerve injury model. Activation of mTOR by deleting phosphatase and tensin homolog (PTEN) or tuberous sclerosis complex 1/2 (TSC1/2), the upstream cytosolic HDAC5 (histone deacetylase 5), Wnt10b (wingless-type MMTV integration site family, member 10b), and melanopsin/GPCR (cell-type-specific $\mathrm{G}$ protein-coupled receptor) robustly enhances the regeneration of retinal ganglion cells (RGCs). Combinational therapies augment the RGCs long-distance regeneration for visual function recovery through overexpression of Ras homolog enriched in brain (Rheb); the dual deletion of PTEN and suppressor of cytokine signaling 3 (SOCS3); deficiency of PTEN combined with injecting of cyclic adenosine monophosphate (cAMP) or inflammatory molecules (oncomodulin or zymosan). However, the excessive mTOR activation of astrocytes contributes to forming glial scar to inhibit axonal regeneration. (B) The spinal cord injury (SCI) model. In spinal cord crush model, the activated mTOR of astrocytes facilitates glial scar formation resulting in impeding the spinal cord regeneration after SCI. In the hemisection model, the stimulation of mTOR promotes the corticospinal tract (CST) regeneration post-SCI. (C) A schematic representation of skeletal muscle regeneration. mTORC1 stimulates satellite cells activation and proliferation, and their progenies differentiate into myoblasts under mTORC1 regulation. mTORC1 also promotes the fusion of myoblasts to form myofibers. (D) Partial hepatectomy $(\mathrm{PH})$ model. Liver regeneration after $\mathrm{PH}$ is via the self-replication of existing hepatocytes, and mTORC1 regulates hepatocyte proliferation. (E) The severe liver injury model. Liver regeneration is via the trans-differentiation of cholangiocytes. In the process, mTORC1 regulates the proliferation of cholangiocytes and the formation of Bi-potential Progenitor Cells.

The spinal cord connects the brain with the PNS. Spinal cord injuries (SCI) are divided into traumatic and non-traumatic aetiologies [112]. Mechanisms of spinal cord regeneration are of great significance for post-SCI clinic therapy. In the animal model of SCI, the epidermal growth factor (EGF) receptor promotes transformation of inactivated astrocytes into a reactive status, which forms a glial scar to restrict neuronal recovery. The activation of astrocytes by EGF is dependent on the Rheb/mTOR pathway $[113,114]$. Chen et al. also showed that the PI3K/Akt/mTOR pathway contributes to the formation of glial scars by reactive astrocytes. Moreover, the overexpression of PTEN can attenuate 
gliosis at three days after SCI and enhances motor functional recovery [115]. In conclusion, hyperactive mTOR in astrocytes is a negative regulator for the functional recovery following SCI $[114,116]$. However, in different injury models like spinal cord hemisection, mTOR activation, stimulated by the deficiency of PTEN or contactin-6 (NB-3) as well as by injection with interleukin (IL-6) or small molecule PF-4708671 (an inhibitor of downstream substrate S6 kinase 1) efficiently promotes regrowth and regeneration of the corticospinal tract [117-121] (Figure 3B). mTOR also increases DRGs regrowth and functional recovery following PNS injury [122-126]. In summary, functions of mTOR in different neuronal injury models can be different or even opposing, which might be caused by mTOR activities in different cell types. Promotion of axonal regeneration can be achieved either by the inhibition of mTOR in astrocytes to attenuate glial scar formation, or by the activation of mTOR in neurons.

\section{Roles of mTOR in Skeletal Muscle Regeneration}

Muscle can quickly regenerate to recover its function after nearly complete myofiber destruction. It is important to maintain the physiological homeostasis of muscle throughout life [127]. Many studies have demonstrated that the quiescent satellite cells, which are believed to be resident muscle stem cells (MuSCs) and localized between the plasmalemma of myofibers and the basement membrane, mainly contribute to the skeletal muscle regeneration in response to muscle injury [128-132]. After muscle injury, satellite cells are activated to proliferate. Their progenies either maintain the satellite cells pool through self-renewal or differentiate into myoblasts expressing myogenic markers Myf5 (myogenic factor 5), MyoD (myogenic differentiation 1), myogenin and MRF4 (myogenic regulatory factor 4) $[130,133]$ (Figure 3C). Ultimately, nascent myoblasts fuse together or fuse to existing myofibers to form new myofibers to accomplish skeletal muscle regeneration [130]. In different models of muscle injury, this process is regulated by multiple pathways such as AMPK, IGF-1/Akt, TGF $\beta /$ Smad and mTOR $[127,130,133-137]$. Here we focus on the roles of mTOR in the regulation of skeletal muscle regeneration.

In mice, conditional knockout (cKO) of mtor or raptor in MuSCs effectively inhibits activation, proliferation, and differentiation of satellite cells, which impairs skeletal muscle regeneration [133-137] (Figure 3C). Rapamycin treatment also confirms that mTOR inhibition indeed blocks the formation of nascent myofibers and the growth of regenerating myofibers during skeletal muscle regeneration $[134,136]$. Rapamycin-resistant (RR) and RR/kinase-inactive (RR/KI) experiments demonstrate that mTORC1 signaling regulates muscle regeneration through both kinase-independent and kinase-dependent mechanisms [134]. S6K1 is dispensable for the initial formation of nascent myofiber during regeneration, but its ablation impairs later muscle growth [134]. Ablation of 4EBP1 facilitates myofiber growth, but does not affect the activation of satellite cells [137]. After injury, activation of Per-Arnt-Sim domain kinase (PASK), a downstream phosphorylation target of mTORC1, phosphorylates Wdr5 to induce the expression of myogenin and stimulates MuSCs differentiation into myoblasts [138] (Figure 3C). The mTORC1-S6K pathway is also required for myoblasts fusion to accomplish myofiber formation during muscle regeneration [138]. micro-RNAs (miRNAs) have been reported as important modulators of myoblasts formation and fusion during muscle regeneration [139-142]. micro-RNA-1 (miR-1) stimulated by mTORC1 increases myoblast differentiation and enhances muscle regeneration through the HDAC4-follistatin axis [141]. Similar to miRNAs, long non-coding RNAs (lncRNAs) also regulate skeletal muscle regeneration. The lncRNA LINC00961 encodes a polypeptide small regulatory polypeptide of amino acid response (SPAR), which negatively regulates mTORC1 activation by interacting with lysosomal v-ATPase. The downregulation of SPAR after skeletal muscle injury activates mTORC1 to enhance muscle regeneration [143]. In contrast to mTORC1, rictor knockout in embryonic and adult satellite cells is ineffective in skeletal muscle regeneration [136,144]. After trauma, the presence of bone-derived and cardiac muscle-derived tissue ECM scaffolds in damaged muscle recruits more immune cells and form immune microenvironment, which facilitates muscle regeneration. Transplanted WT CD4 ${ }^{+} \mathrm{T}$ cells rather than rictor $^{-/-} \mathrm{CD}^{+} \mathrm{T}$ cells promote muscle regeneration in the 
Rag $1^{-/-}$mice [145]. Taken together, these studies illustrate that mTORC1, but not mTORC2, acts as a key regulator of skeletal muscle regeneration.

In muscle injury-regeneration models induced by cardiotoxin (CTX) [146], $\mathrm{BaCl}_{2}$ [142] and ischemia/reperfusion (I/R) [147], some pathways regulate muscle regeneration through mTOR signaling. In I/R-induced muscle injury, skeletal muscle protection by activated Sonic hedgehog (Shh) is blocked by the inhibition of AKT/mTOR/p70S6K [147]. This result implies that Shh stimulates skeletal muscle regeneration through the AKT/mTOR/p70S6K pathway. In CTX-induced muscle injury, $\mathrm{Ca}^{2+}$ influx flows into cells through T-type $\mathrm{Ca}^{2+}$ and Trpc1 channels, which enhances the activation of PI3K to activate the Akt/mTOR/p70S6K pathway and ultimately improves muscle regeneration [146]. The IGF pathway is essential for skeletal muscle regeneration [148,149]. mTORC1 inhibits miR-125b, which is a negative regulator of IGF2, thus promoting muscle regeneration after $\mathrm{BaCl}_{2}$ treatment [142]. Furthermore, nutmeg extract stimulates soleus muscle regeneration through IGF1-AKT-mTOR and inhibits autophagy in aged rats [150].

Muscle-mass weakness and wasting are often caused by various pathological conditions, such as sarcopenia, diabetes and chronic obstructive pulmonary disease (COPD). On average, geriatric patients with sarcopenia lose $30 \%$ of their muscle mass and $35 \%$ of myofibers [151], and have decreased muscle protein synthesis [152]. Studies on aged rodents clarify that aging decreases the muscle regenerative capacity after injury [152-154]. Comparing to the aged rodents, young rodents with leucine supplements strongly improve skeletal muscle regeneration. During muscle injury, both aged and young rodents activate Akt/mTOR pathway, p70S6K and 4EBP1, but the young rodents have stronger activation than aged ones. Leucine supplementation increases the activation of the PI3K/Akt/mTOR pathway, then improves muscle regeneration in aged rodents [155-159]. However, homeostatic maintenance of MuSCs pool is also critical to ensure muscle regeneration upon re-injury in aged muscles $[160,161]$. Upon repeated injuries, differentiation of MuSCs at the expense of MuSCs is promoted by mTORC1 in aged mice, which can be inhibited by rapamycin [162]. In mice, skeletal muscle atrophy can be induced by diabetes. Acupuncture with low-frequency-electric-stimulation (Acu-LFES) promotes muscle regeneration through the IGF-1-Akt-mTOR pathway [163]. The muscle regeneration stimulated by the Acu-LFES induced miR-1 may also act through the mTORC1-miR-1-HDAC4-follistatin axis [141,163]. In mice with hypoxic treatment, mTOR is inhibited by the activated AMPK or REDD1 (regulated in development and DNA response 1), both of which impair muscle regeneration [164]. Muscle injury and the decreased mTOR activity are observed in COPD patients with hypoxemia [165]. At present, there are drugs/targets to be used in clinical trials to treat muscle wasting. However, drugs targeting mTOR signaling have not been trialed yet [166], which may be of future clinical interest to inhibit muscle atrophy and promote muscle regeneration.

\section{Roles of mTOR in Liver Regeneration}

The liver possesses extraordinary regenerative capacity comparing to other internal organs [167-169]. Partial hepatectomy $(\mathrm{PH})$ of rats and mice is one of the most widely used models to study liver regeneration [170,171]. In 1931, Higgins et al. first proposed a rat model with 2/3 hepatectomy, in which the remaining liver restores its original weight after 5-7 days of surgical resection [168] (Figure 3D). Other acute injury models include tetrachloride $\left(\mathrm{CCl}_{4}\right)$ - and thioacetamide (TAA)-induced chemical liver injury. Remaining hepatocytes after $\mathrm{PH}$ or chemical liver injury accomplish liver regeneration via self-replication without the participation of progenitor cells $[168,172]$. However, chronic liver diseases in humans cause severe liver injury and impair hepatocyte proliferation [173]. After extreme liver damage, regeneration is achieved via cholangiocytes transdifferentiation rather than self-replication, in zebrafish $[174,175]$ and mice $[176,177]$ (Figure 3E). The mTOR signaling pathway mediates liver regeneration after $\mathrm{PH}$ and initiates the transdifferentiation of biliary epithelial cells (BECs) after extreme liver injury [178,179].

A 2/3 hepatectomy in rodents promotes the release of cytokines and growth factors [171], which simulate hepatocyte proliferation via transducing activation of PI3K/Akt signaling pathway [180]. 
The "pif-pocket" mutant of PDK1 showed that the PI3K-dependent PDK1 kinase specially phosphorylates Akt during regeneration after $\mathrm{PH}$ [181]. In mice, deletion of vitamin D3 up-regulated protein 1 (VDUP1) enhances regeneration after PH via the HGF and TGF- $\alpha$ responsive activation of ERK1/2 and Akt $[182,183]$. In VDUP1 KO mice, 70\% hepatectomy significantly increases the hepatic proliferative response, in accordance with $\mathrm{CCl}_{4}$ treatment [183]. mTOR activated by Akt activation is well-conserved in the regulation of cell cycle and cell proliferation during liver regeneration [184] (Figure 3D). Hepatocyte proliferation in liver regeneration is regulated by cell cycle-related proteins, such as cyclin dependent kinase (CDK), cyclin D, cyclin E [185]. However, phosphorylation and activation of S6K1 by mTOR is vital to regulate the expression of cell cycle-related proteins, particularly cyclin D1, during liver regeneration [186]. After $\mathrm{PH}$, rapamycin significantly reduces the rate of hepatic proliferation through inhibition of p70S6K activation, but not inhibition of p4EBP1 [187]. Meanwhile, it increases the rate of hepatic apoptosis [188] and significantly eliminates bleeding-induced hepatocyte hypertrophy [189]. After 2/3 hepatectomy, Cyclin D1 translation promoted by microRNA-21 (miR-21) enhances liver regeneration via eliminating the inhibition of Ras homolog gene family member B (Rhob) on Akt1/mTORC1 [190]. Cyclin D1 and CDK4 form an activation complex to promote liver regeneration via stimulation of G1 to S transition in hepatocytes [185]. Deletion of sirtuin6 (sirt6), one of the sirtuin family of class III NAD ${ }^{+}$-dependent histone deacetylase, delays $\mathrm{G} 1$ to $S$ phase transition and impairs activation of the Akt/mTOR pathway during liver regeneration [191]. However, SIRT1 overexpression in mice impairs liver regeneration, which can be reversed by the leucine-activated mTORC1 [192]. Genetic manipulation or chemical drugs treatment, such as inactivation of apoptosis-stimulating protein two of p53 (ASPP2) [193], let-7 deletion [194], rosmarinic acid [195], carbamazepine [196], and panax notoginseng saponins [197], stimulate liver regeneration by activation of mTOR after PH, which is blocked by the mTOR inhibition [194-196]. Severe injury in PH such as a $90 \%$ hepatectomy suppresses the capacity of liver regeneration, which is accompanied by the inactive mTOR signaling [198]. In addition to hepatocyte proliferation, increases in the hepatocyte size could account for liver regeneration [181,184,199]. In liver-specific STAT3-knockout (LS3-KO) mice, although hepatocyte proliferation after injury is impaired by the decreased cyclin D1 expression, increases in hepatocyte size during early liver regeneration may occur via the activation of the PI3K/Akt/mTOR pathway [181,199].

Contributions of non-parenchymal cells (NPCs) can also be important for liver regeneration $[174,176,177,179,200]$. Expansion of BECs during ductular reaction (DR) is promoted by mTORC1 signaling after extreme liver injury in zebrafish and mice $[179,200]$ (Figure 3E). Inhibition of mTORC1 remarkably suppresses the dedifferentiation of BECs and the proliferation of bi-potential progenitor cells (BP-PCs), thus leading to a reduced number of BP-PCs for re-differentiation and impairing liver regeneration after extreme injury $[179,200]$. Estrogen promotes liver regeneration through the activation of mTORC1 signaling in zebrafish [201]. In contrast, the rictor mutant only loses $20 \%$ of regenerating liver mass compared to the wild-type [179]. These studies suggest that liver regeneration is mainly mediated by mTORC1 rather than mTORC2 signaling [179].

In addition to endogenous liver regeneration, liver transplantation is also an effective way to restore liver mass and functions after liver failure or cirrhosis [202,203]. In patients, associating liver partition with portal vein ligation during staged hepatectomy (ALPPS) activates mTORC1 signaling [204]. Small-for-size mouse liver transplantation (30\% grafts) significantly downregulate mTORC1 signaling and suppress liver regeneration $[205,206]$. However, half-size transplantation (50\% grafts) increases the mTORC 1 activity. $30 \%$ grafts treated with amphiregulin restore mTORC 1 activation and p70S6K phosphorylation to the level of 50\% grafts [206]. These studies imply that activation of mTORC1 may be a promising therapeutic approach to stimulate liver regeneration during liver transplantation.

\section{Roles of mTOR in Intestinal Regeneration}

The small intestinal epithelium is a single cell layer with rapid self-renewing and strong regenerative capabilities. The mammalian intestinal epithelium mainly includes enterocytes, Goblet cells, enteroendocrine cells, and Paneth cells [207]. In flies, esg ${ }^{+}$(escargot) intestinal stem cells 
(ISCs) and enteroblasts (EBs) are responsible for gut homeostasis and drive the regeneration following injury $[208,209]$. The TSC/TOR signaling pathway regulates proliferation and maintenance of ISCs in response to nutritional conditions [162,210]. Also, mTORC1 is the main component of mTOR pathway that is decisive for the intestinal development in zebrafish [211]. Similarly, Lgr5 marks the ISCs at the base of intestinal crypt which maintain the intestinal homeostasis and intestinal regeneration in mouse [212]. Furthermore, $\mathrm{Dll1}^{+}$secretory progenitor cells, Alpi ${ }^{+}$enterocyte progenitor cells, and $\mathrm{Lyz}^{+}$Paneth cells can be induced to ISC after specific ablation of $L g r 5^{+}$ISC [213-215]. mTORC1 takes an pivotal part in increasing the maintenance of ISCs activity and proliferation of intestinal epithelium [216]. In addition, the cooperation of mTORC1 and SIRT1 promotes the expansion of ISCs during the calorie restriction (CR) [217]. Taken together, mTORC1 regulates the intestinal development and maintains intestinal hemostasis and ISC, in which mTOR is conserved in drosophila, zebrafish and mouse.

The intestinal epithelium, which has a powerful regenerative capacity after injury, provides a model to study ISCs, cancer, and intestinal regeneration [218]. A few studies demonstrate that mTORC1 signaling is required for intestinal regeneration and conserved in Drosophila and mammals. In inflammatory bowel disease (IBD) mouse models induced by 2,4,6-trinitrobenzene sulfonic acid (TNBS) or dextran sodium sulfate (DSS), mTORC1 is required for intestinal regeneration against IBD. The deficiency of Regnase-1 promotes the intestinal regeneration in the acute IBD via controlling the mTOR and purine metabolism [219]. Akt/mTOR activated by the focal adhesion kinase (FAK) is required for the Wnt/myc-mediated intestinal regeneration and tumorigenesis $[218,220]$. mTORC1-S6k1/2 axis, but not eiF4ebp1/2, enhances crypt regeneration after DNA damage [221]. These studies imply that activation of mTORC1 may become a therapeutic approach for IBD and other intestinal injuries [222]. Besides, the mTOR-dependent autophagy is impaired in patients with ulcerative colitis (UC), implicating mTOR also as a therapeutic target for autoimmune diseases [223].

\section{Perspectives}

In this review, we summarize the roles of mTOR in the regeneration of neurons, muscles, the liver, and the intestine, which are mainly mediated by mTORC1 rather than MTORC2 signaling. The mTORC1 signaling network may be disrupted in various diseases, such as ALS, AD, PD, COPD, sarcopenia, liver failure, and IBD, which is harmful to tissue regeneration [151,165,203,222,224-226]. Although regeneration and recovery of injured tissues in human may be improved by drugs promoting mTOR such as carbamazepine and nutmeg $[150,196,224,225]$, mechanisms underlying these drugs remain largely unknown. And the curative effects of these drugs still need improvements. Additionally, the agonist and inhibitor of mTOR lack tissue specificities, like leucine and rapamycin [2,225]. For example, in addition to the inhibition of mTORC1, rapamycin can also inhibit mTORC2 during a long-term treatment [225]. A large number of studies have reported that drug delivery systems can increase tissue specificity. For example, a bone-targeted nanoparticle (NP) delivery system can carry a $\beta$-catenin agonist or GSK3 $\beta$ inhibitor to fractured bone with concentrated accumulation, which enhances bone regeneration [227]. A tissue-specific agonist or antagonist of mTORC1 might also be achieved with this strategy. Tissue-specific mTORC1-antagonist may effectively treat neurodegenerative diseases resulting in nerve injury, and tissue-specific mTORC1-agonist may effectively promote muscle recovery in muscle injury. Recently, sirolimus in phase $1 / 2$ trial has been shown to effectively treat patients with systemic lupus erythematosus (SLE) against tissue injury, improving the expansion of naïve T-cell populations and decreasing $\mathrm{CD} 8^{+}$memory $\mathrm{T}$ cells. But in this process, sirolimus causes reversible oral ulcers, headaches, and cytopenia [228]. The tissue-specific inhibitor of mTORC1 may prevent these side-effects in the clinic. Except organs depicted in this review, roles of mTOR signaling in the regeneration of other organs like the pancreas, heart, and kidney are rarely reported. Ultimately, a comprehensive understanding of the mTOR signaling network during different tissue regeneration processes, and the development of new drugs for tissue-specific mTOR activation or inhibition are of great scientific and clinical interest. 
Funding: This work was supported by the National Key Basic Research Program of China (2015CB942800), National Natural Science Foundation of China (31730060, 91539201, and 91739304), and the 111 Program (B14037).

Acknowledgments: We would like to thank Mengzhu Lv for pictures and Xinmiao Tan, Rui Ye and Guozhen Wu for help and discussions.

Conflicts of Interest: The authors declare no conflict of interest.

\section{References}

1. Saxton, R.A.; Sabatini, D.M. mTOR Signaling in Growth, Metabolism, and Disease. Cell 2017, 168, 960-976. [CrossRef] [PubMed]

2. Johnson, S.C.; Rabinovitch, P.S.; Kaeberlein, M. mTOR is a key modulator of ageing and age-related disease. Nature 2013, 493, 338-345. [CrossRef] [PubMed]

3. Chung, J.; Kuo, C.J.; Crabtree, G.R.; Blenis, J. Rapamycin-FKBP specifically blocks growth-dependent activation of and signaling by the $70 \mathrm{kd}$ S6 protein kinases. Cell 1992, 69, 1227-1236. [CrossRef]

4. Brown, E.J.; Albers, M.W.; Shin, T.B.; Keith, C.T.; Lane, W.S.; Schreiber, S.L. A mammalian protein targeted by G1-arresting rapamycin-receptor complex. Nature 1994, 369, 756-758. [CrossRef] [PubMed]

5. Oh, W.J.; Jacinto, E. mTOR complex 2 signaling and functions. Cell Cycle 2011, 10, 2305-2316. [CrossRef] [PubMed]

6. Kim, J.; Guan, K.L. mTOR as a central hub of nutrient signalling and cell growth. Nat. Cell Biol. 2019, $21,63-71$. [CrossRef]

7. Liu, P.; Gan, W.; Chin, Y.R.; Ogura, K.; Guo, J.; Zhang, J.; Wang, B.; Blenis, J.; Cantley, L.C.; Toker, A.; et al. PtdIns(3,4,5)P3-Dependent Activation of the mTORC2 Kinase Complex. Cancer Discov. 2015, 5, 1194-1209. [CrossRef]

8. Simioni, C.; Martelli, A.M.; Zauli, G.; Melloni, E.; Neri, L.M. Targeting mTOR in Acute Lymphoblastic Leukemia. Cells 2019, 8, 190. [CrossRef]

9. Kou, X.; Chen, D.; Chen, N. Physical Activity Alleviates Cognitive Dysfunction of Alzheimer's Disease through Regulating the mTOR Signaling Pathway. Int. J. Mol. Sci. 2019, 20, 1591. [CrossRef]

10. Kim, L.C.; Cook, R.S.; Chen, J. mTORC1 and mTORC2 in cancer and the tumor microenvironment. Oncogene 2017, 36, 2191-2201. [CrossRef]

11. Chakrabarti, P.; Kandror, K.V. The role of mTOR in lipid homeostasis and diabetes progression. Curr. Opin. Endocrinol. Diabetes Obes. 2015, 22, 340-346. [CrossRef] [PubMed]

12. Perl, A. mTOR activation is a biomarker and a central pathway to autoimmune disorders, cancer, obesity, and aging. Ann. N. Y. Acad. Sci. 2015, 1346, 33-44. [CrossRef] [PubMed]

13. Martelli, A.M.; Buontempo, F.; McCubrey, J.A. Drug discovery targeting the mTOR pathway. Clin. Sci. (Lond.) 2018, 132, 543-568. [CrossRef] [PubMed]

14. Moya, I.M.; Halder, G. Hippo-YAP/TAZ signalling in organ regeneration and regenerative medicine. Nat. Rev. Mol. Cell Biol. 2019, 20, 211-226. [CrossRef] [PubMed]

15. Baddour, J.A.; Sousounis, K.; Tsonis, P.A. Organ repair and regeneration: An overview. Birth Defects Res. C Embryo Today 2012, 96, 1-29. [CrossRef] [PubMed]

16. Park, K.K.; Liu, K.; Hu, Y.; Smith, P.D.; Wang, C.; Cai, B.; Xu, B.; Connolly, L.; Kramvis, I.; Sahin, M.; et al. Promoting axon regeneration in the adult CNS by modulation of the PTEN/mTOR pathway. Science 2008, 322, 963-966. [CrossRef]

17. Shimobayashi, M.; Hall, M.N. Making new contacts: The mTOR network in metabolism and signalling crosstalk. Nat. Rev. Mol. Cell Biol. 2014, 15, 155-162. [CrossRef] [PubMed]

18. Sciarretta, S.; Forte, M.; Frati, G.; Sadoshima, J. New Insights Into the Role of mTOR Signaling in the Cardiovascular System. Circ. Res. 2018, 122, 489-505. [CrossRef]

19. Yang, Q.; Guan, K.L. Expanding mTOR signaling. Cell Res. 2007, 17, 666-681. [CrossRef]

20. Kim, D.H.; Sarbassov, D.D.; Ali, S.M.; King, J.E.; Latek, R.R.; Erdjument-Bromage, H.; Tempst, P.; Sabatini, D.M. mTOR interacts with raptor to form a nutrient-sensitive complex that signals to the cell growth machinery. Cell 2002, 110, 163-175. [CrossRef]

21. Kim, D.H.; Sarbassov, D.D.; Ali, S.M.; Latek, R.R.; Guntur, K.V.; Erdjument-Bromage, H.; Tempst, P.; Sabatini, D.M. GbetaL, a positive regulator of the rapamycin-sensitive pathway required for the nutrient-sensitive interaction between raptor and mTOR. Mol. Cell 2003, 11, 895-904. [CrossRef] 
22. Hara, K.; Maruki, Y.; Long, X.; Yoshino, K.; Oshiro, N.; Hidayat, S.; Tokunaga, C.; Avruch, J.; Yonezawa, K. Raptor, a binding partner of target of rapamycin (TOR), mediates TOR action. Cell 2002, 110, 177-189. [CrossRef]

23. Sancak, Y.; Thoreen, C.C.; Peterson, T.R.; Lindquist, R.A.; Kang, S.A.; Spooner, E.; Carr, S.A.; Sabatini, D.M. PRAS40 is an insulin-regulated inhibitor of the mTORC1 protein kinase. Mol. Cell 2007, 25, 903-915. [CrossRef] [PubMed]

24. Vander Haar, E.; Lee, S.I.; Bandhakavi, S.; Griffin, T.J.; Kim, D.H. Insulin signalling to mTOR mediated by the Akt/PKB substrate PRAS40. Nat. Cell Biol. 2007, 9, 316-323. [CrossRef] [PubMed]

25. Peterson, T.R.; Laplante, M.; Thoreen, C.C.; Sancak, Y.; Kang, S.A.; Kuehl, W.M.; Gray, N.S.; Sabatini, D.M. DEPTOR is an mTOR inhibitor frequently overexpressed in multiple myeloma cells and required for their survival. Cell 2009, 137, 873-886. [CrossRef] [PubMed]

26. Yang, H.; Rudge, D.G.; Koos, J.D.; Vaidialingam, B.; Yang, H.J.; Pavletich, N.P. mTOR kinase structure, mechanism and regulation. Nature 2013, 497, 217-223. [CrossRef] [PubMed]

27. Sabatini, D.M. Twenty-five years of mTOR: Uncovering the link from nutrients to growth. Proc. Natl. Acad. Sci. USA 2017, 114, 11818-11825. [CrossRef]

28. Dibble, C.C.; Elis, W.; Menon, S.; Qin, W.; Klekota, J.; Asara, J.M.; Finan, P.M.; Kwiatkowski, D.J.; Murphy, L.O.; Manning, B.D. TBC1D7 is a third subunit of the TSC1-TSC2 complex upstream of mTORC1. Mol. Cell 2012, 47, 535-546. [CrossRef]

29. Menon, S.; Dibble, C.C.; Talbott, G.; Hoxhaj, G.; Valvezan, A.J.; Takahashi, H.; Cantley, L.C.; Manning, B.D. Spatial control of the TSC complex integrates insulin and nutrient regulation of mTORC1 at the lysosome. Cell 2014, 156, 771-785. [CrossRef]

30. Ma, L.; Chen, Z.; Erdjument-Bromage, H.; Tempst, P.; Pandolfi, P.P. Phosphorylation and functional inactivation of TSC2 by Erk implications for tuberous sclerosis and cancer pathogenesis. Cell 2005, 121, 179-193. [CrossRef]

31. Bai, X.; Ma, D.; Liu, A.; Shen, X.; Wang, Q.J.; Liu, Y.; Jiang, Y. Rheb activates mTOR by antagonizing its endogenous inhibitor, FKBP38. Science 2007, 318, 977-980. [CrossRef] [PubMed]

32. Yang, H.; Jiang, X.; Li, B.; Yang, H.J.; Miller, M.; Yang, A.; Dhar, A.; Pavletich, N.P. Mechanisms of mTORC1 activation by RHEB and inhibition by PRAS40. Nature 2017, 552, 368-373. [CrossRef] [PubMed]

33. Ye, J.; Palm, W.; Peng, M.; King, B.; Lindsten, T.; Li, M.O.; Koumenis, C.; Thompson, C.B. GCN2 sustains mTORC1 suppression upon amino acid deprivation by inducing Sestrin2. Genes Dev. 2015, 29, 2331-2336. [CrossRef] [PubMed]

34. Chantranupong, L.; Scaria, S.M.; Saxton, R.A.; Gygi, M.P.; Shen, K.; Wyant, G.A.; Wang, T.; Harper, J.W.; Gygi, S.P.; Sabatini, D.M. The CASTOR Proteins Are Arginine Sensors for the mTORC1 Pathway. Cell 2016, 165, 153-164. [CrossRef] [PubMed]

35. Rebsamen, M.; Pochini, L.; Stasyk, T.; de Araujo, M.E.; Galluccio, M.; Kandasamy, R.K.; Snijder, B.; Fauster, A.; Rudashevskaya, E.L.; Bruckner, M.; et al. SLC38A9 is a component of the lysosomal amino acid sensing machinery that controls mTORC1. Nature 2015, 519, 477-481. [CrossRef] [PubMed]

36. Goberdhan, D.C.; Wilson, C.; Harris, A.L. Amino Acid Sensing by mTORC1: Intracellular Transporters Mark the Spot. Cell Metab. 2016, 23, 580-589. [CrossRef] [PubMed]

37. Jewell, J.L.; Russell, R.C.; Guan, K.L. Amino acid signalling upstream of mTOR. Nat. Rev. Mol. Cell Biol. 2013, 14, 133-139. [CrossRef] [PubMed]

38. Jewell, J.L.; Kim, Y.C.; Russell, R.C.; Yu, F.X.; Park, H.W.; Plouffe, S.W.; Tagliabracci, V.S.; Guan, K.L. Metabolism. Differential regulation of mTORC1 by leucine and glutamine. Science 2015, 347, 194-198. [CrossRef]

39. Tsun, Z.Y.; Bar-Peled, L.; Chantranupong, L.; Zoncu, R.; Wang, T.; Kim, C.; Spooner, E.; Sabatini, D.M. The folliculin tumor suppressor is a GAP for the RagC/D GTPases that signal amino acid levels to mTORC1. Mol. Cell 2013, 52, 495-505. [CrossRef]

40. Feng, Z.; Hu, W.; de Stanchina, E.; Teresky, A.K.; Jin, S.; Lowe, S.; Levine, A.J. The regulation of AMPK beta1, TSC2, and PTEN expression by p53: Stress, cell and tissue specificity, and the role of these gene products in modulating the IGF-1-AKT-mTOR pathways. Cancer Res. 2007, 67, 3043-3053. [CrossRef]

41. Gwinn, D.M.; Shackelford, D.B.; Egan, D.F.; Mihaylova, M.M.; Mery, A.; Vasquez, D.S.; Turk, B.E.; Shaw, R.J. AMPK phosphorylation of raptor mediates a metabolic checkpoint. Mol. Cell 2008, 30, 214-226. [CrossRef] [PubMed] 
42. Inoki, K.; Zhu, T.; Guan, K.-L. TSC2 Mediates Cellular Energy Response to Control Cell Growth and Survival. Cell 2003, 115, 577-590. [CrossRef]

43. Inoki, K.; Ouyang, H.; Zhu, T.; Lindvall, C.; Wang, Y.; Zhang, X.; Yang, Q.; Bennett, C.; Harada, Y.; Stankunas, K.; et al. TSC2 integrates Wnt and energy signals via a coordinated phosphorylation by AMPK and GSK3 to regulate cell growth. Cell 2006, 126, 955-968. [CrossRef] [PubMed]

44. Lee, D.F.; Kuo, H.P.; Chen, C.T.; Hsu, J.M.; Chou, C.K.; Wei, Y.; Sun, H.L.; Li, L.Y.; Ping, B.; Huang, W.C.; et al. IKK beta suppression of TSC1 links inflammation and tumor angiogenesis via the mTOR pathway. Cell 2007, 130, 440-455. [CrossRef] [PubMed]

45. Nojima, H.; Tokunaga, C.; Eguchi, S.; Oshiro, N.; Hidayat, S.; Yoshino, K.; Hara, K.; Tanaka, N.; Avruch, J.; Yonezawa, K. The mammalian target of rapamycin (mTOR) partner, raptor, binds the mTOR substrates p70 S6 kinase and 4E-BP1 through their TOR signaling (TOS) motif. J. Biol. Chem. 2003, 278, 15461-15464. [CrossRef] [PubMed]

46. Holz, M.K.; Ballif, B.A.; Gygi, S.P.; Blenis, J. mTOR and S6K1 mediate assembly of the translation preinitiation complex through dynamic protein interchange and ordered phosphorylation events. Cell 2005, 123, 569-580. [CrossRef]

47. Dorrello, N.V.; Peschiaroli, A.; Guardavaccaro, D.; Colburn, N.H.; Sherman, N.E.; Pagano, M. S6K1and betaTRCP-mediated degradation of PDCD4 promotes protein translation and cell growth. Science 2006, 314, 467-471. [CrossRef] [PubMed]

48. Ruvinsky, I.; Meyuhas, O. Ribosomal protein S6 phosphorylation: From protein synthesis to cell size. Trends Biochem. Sci. 2006, 31, 342-348. [CrossRef]

49. Ma, X.M.; Yoon, S.O.; Richardson, C.J.; Julich, K.; Blenis, J. SKAR links pre-mRNA splicing to mTOR/S6K1-mediated enhanced translation efficiency of spliced mRNAs. Cell 2008, 133, 303-313. [CrossRef]

50. Gingras, A.C.; Gygi, S.P.; Raught, B.; Polakiewicz, R.D.; Abraham, R.T.; Hoekstra, M.F.; Aebersold, R.; Sonenberg, N. Regulation of 4E-BP1 phosphorylation: A novel two-step mechanism. Genes Dev. 1999, 13, 1422-1437. [CrossRef]

51. Peterson, T.R.; Sengupta, S.S.; Harris, T.E.; Carmack, A.E.; Kang, S.A.; Balderas, E.; Guertin, D.A.; Madden, K.L.; Carpenter, A.E.; Finck, B.N.; et al. mTOR complex 1 regulates lipin 1 localization to control the SREBP pathway. Cell 2011, 146, 408-420. [CrossRef] [PubMed]

52. Ben-Sahra, I.; Hoxhaj, G.; Ricoult, S.J.H.; Asara, J.M.; Manning, B.D. mTORC1 induces purine synthesis through control of the mitochondrial tetrahydrofolate cycle. Science 2016, 351, 728-733. [CrossRef] [PubMed]

53. Duvel, K.; Yecies, J.L.; Menon, S.; Raman, P.; Lipovsky, A.I.; Souza, A.L.; Triantafellow, E.; Ma, Q.; Gorski, R.; Cleaver, S.; et al. Activation of a metabolic gene regulatory network downstream of mTOR complex 1. Mol. Cell 2010, 39, 171-183. [CrossRef] [PubMed]

54. Kim, J.; Kundu, M.; Viollet, B.; Guan, K.L. AMPK and mTOR regulate autophagy through direct phosphorylation of Ulk1. Nat. Cell Biol. 2011, 13, 132-141. [CrossRef] [PubMed]

55. Martina, J.A.; Chen, Y.; Gucek, M.; Puertollano, R. MTORC1 functions as a transcriptional regulator of autophagy by preventing nuclear transport of TFEB. Autophagy 2012, 8, 903-914. [CrossRef] [PubMed]

56. Sarbassov, D.D.; Ali, S.M.; Kim, D.H.; Guertin, D.A.; Latek, R.R.; Erdjument-Bromage, H.; Tempst, P.; Sabatini, D.M. Rictor, a novel binding partner of mTOR, defines a rapamycin-insensitive and raptor-independent pathway that regulates the cytoskeleton. Curr. Biol. 2004, 14, 1296-1302. [CrossRef] [PubMed]

57. Frias, M.A.; Thoreen, C.C.; Jaffe, J.D.; Schroder, W.; Sculley, T.; Carr, S.A.; Sabatini, D.M. mSin1 is necessary for Akt/PKB phosphorylation, and its isoforms define three distinct mTORC2s. Curr. Biol. 2006, 16, 1865-1870. [CrossRef]

58. Woo, S.Y.; Kim, D.H.; Jun, C.B.; Kim, Y.M.; Haar, E.V.; Lee, S.I.; Hegg, J.W.; Bandhakavi, S.; Griffin, T.J.; Kim, D.H. PRR5, a novel component of mTOR complex 2, regulates platelet-derived growth factor receptor beta expression and signaling. J. Biol. Chem. 2007, 282, 25604-25612. [CrossRef]

59. Lamming, D.W.; Ye, L.; Katajisto, P.; Goncalves, M.D.; Saitoh, M.; Stevens, D.M.; Davis, J.G.; Salmon, A.B.; Richardson, A.; Ahima, R.S.; et al. Rapamycin-induced insulin resistance is mediated by mTORC2 loss and uncoupled from longevity. Science 2012, 335, 1638-1643. [CrossRef]

60. Yang, G.; Murashige, D.S.; Humphrey, S.J.; James, D.E. A Positive Feedback Loop between Akt and mTORC2 via SIN1 Phosphorylation. Cell Rep. 2015, 12, 937-943. [CrossRef] 
61. Shah, O.J.; Wang, Z.; Hunter, T. Inappropriate activation of the TSC/Rheb/mTOR/S6K cassette induces IRS1/2 depletion, insulin resistance, and cell survival deficiencies. Curr. Biol. 2004, 14, 1650-1656. [CrossRef] [PubMed]

62. Gan, X.; Wang, J.; Wang, C.; Sommer, E.; Kozasa, T.; Srinivasula, S.; Alessi, D.; Offermanns, S.; Simon, M.I.; $\mathrm{Wu}, \mathrm{D}$. PRR5L degradation promotes mTORC2-mediated PKC-delta phosphorylation and cell migration downstream of Galpha12. Nat. Cell Biol. 2012, 14, 686-696. [CrossRef] [PubMed]

63. Li, X.; Gao, T. mTORC2 phosphorylates protein kinase $\mathrm{C} \zeta$ to regulate its stability and activity. EMBO Rep. 2013, 15, 191-198. [CrossRef] [PubMed]

64. Thomanetz, V.; Angliker, N.; Cloetta, D.; Lustenberger, R.M.; Schweighauser, M.; Oliveri, F.; Suzuki, N.; Ruegg, M.A. Ablation of the mTORC2 component rictor in brain or Purkinje cells affects size and neuron morphology. J. Cell Biol. 2013, 201, 293-308. [CrossRef] [PubMed]

65. Guertin, D.A.; Stevens, D.M.; Thoreen, C.C.; Burds, A.A.; Kalaany, N.Y.; Moffat, J.; Brown, M.; Fitzgerald, K.J.; Sabatini, D.M. Ablation in mice of the mTORC components raptor, rictor, or mLST8 reveals that mTORC2 is required for signaling to Akt-FOXO and PKCalpha, but not S6K1. Dev. Cell 2006, 11, 859-871. [CrossRef] [PubMed]

66. Jacinto, E.; Facchinetti, V.; Liu, D.; Soto, N.; Wei, S.; Jung, S.Y.; Huang, Q.; Qin, J.; Su, B. SIN1/MIP1 maintains rictor-mTOR complex integrity and regulates Akt phosphorylation and substrate specificity. Cell 2006, 127, 125-137. [CrossRef] [PubMed]

67. Garcia-Martinez, J.M.; Alessi, D.R. mTOR complex 2 (mTORC2) controls hydrophobic motif phosphorylation and activation of serum- and glucocorticoid-induced protein kinase 1 (SGK1). Biochem. J. 2008, 416, 375-385. [CrossRef] [PubMed]

68. Lee, H.K.; Kwon, B.; Lemere, C.A.; de la Monte, S.; Itamura, K.; Ha, A.Y.; Querfurth, H.W. mTORC2 (Rictor) in Alzheimer's Disease and Reversal of Amyloid-beta Expression-Induced Insulin Resistance and Toxicity in Rat Primary Cortical Neurons. J. Alzheimers Dis. 2017, 56, 1015-1036. [CrossRef] [PubMed]

69. Langen, U.H.; Ayloo, S.; Gu, C. Development and Cell Biology of the Blood-Brain Barrier. Annu. Rev. Cell Dev. Biol. 2019, 35. [CrossRef] [PubMed]

70. Abbott, N.J.; Ronnback, L.; Hansson, E. Astrocyte-endothelial interactions at the blood-brain barrier. Nat. Rev. Neurosci. 2006, 7, 41-53. [CrossRef] [PubMed]

71. Liu, C.; Wu, C.; Yang, Q.; Gao, J.; Li, L.; Yang, D.; Luo, L. Macrophages Mediate the Repair of Brain Vascular Rupture through Direct Physical Adhesion and Mechanical Traction. Immunity 2016, 44, 1162-1176. [CrossRef] [PubMed]

72. Chen, J.; He, J.; Ni, R.; Yang, Q.; Zhang, Y.; Luo, L. Cerebrovascular Injuries Induce Lymphatic Invasion into Brain Parenchyma to Guide Vascular Regeneration in Zebrafish. Dev. Cell 2019, 49, 697-710. [CrossRef] [PubMed]

73. Sousa, A.M.M.; Meyer, K.A.; Santpere, G.; Gulden, F.O.; Sestan, N. Evolution of the Human Nervous System Function, Structure, and Development. Cell 2017, 170, 226-247. [CrossRef] [PubMed]

74. Richner, M.; Ulrichsen, M.; Elmegaard, S.L.; Dieu, R.; Pallesen, L.T.; Vaegter, C.B. Peripheral nerve injury modulates neurotrophin signaling in the peripheral and central nervous system. Mol. Neurobiol. 2014, 50, 945-970. [CrossRef] [PubMed]

75. Hoffman, P.N. A conditioning lesion induces changes in gene expression and axonal transport that enhance regeneration by increasing the intrinsic growth state of axons. Exp. Neurol. 2010, 223, 11-18. [CrossRef] [PubMed]

76. He, Z.; Jin, Y. Intrinsic Control of Axon Regeneration. Neuron 2016, 90, 437-451. [CrossRef] [PubMed]

77. Omura, T.; Omura, K.; Tedeschi, A.; Riva, P.; Painter, M.W.; Rojas, L.; Martin, J.; Lisi, V.; Huebner, E.A.; Latremoliere, A.; et al. Robust Axonal Regeneration Occurs in the Injured CAST/Ei Mouse CNS. Neuron 2015, 86, 1215-1227. [CrossRef] [PubMed]

78. Benowitz, L.I.; Yin, Y. Combinatorial treatments for promoting axon regeneration in the CNS: Strategies for overcoming inhibitory signals and activating neurons' intrinsic growth state. Dev. Neurobiol. 2007, 67, 1148-1165. [CrossRef] [PubMed]

79. Filbin, M.T. Myelin-associated inhibitors of axonal regeneration in the adult mammalian CNS. Nat. Rev. Neurosci. 2003, 4, 703-713. [CrossRef] [PubMed]

80. Fitch, M.T.; Silver, J. CNS injury, glial scars, and inflammation: Inhibitory extracellular matrices and regeneration failure. Exp. Neurol. 2008, 209, 294-301. [CrossRef] [PubMed] 
81. Brown, R.H.; Al-Chalabi, A. Amyotrophic Lateral Sclerosis. N. Engl. J. Med. 2017, 377, 162-172. [CrossRef] [PubMed]

82. Kalia, L.V.; Lang, A.E. Parkinson's disease. Lancet 2015, 386, 896-912. [CrossRef]

83. Ballard, C.; Gauthier, S.; Corbett, A.; Brayne, C.; Aarsland, D.; Jones, E. Alzheimer's disease. Lancet 2011, 377, 1019-1031. [CrossRef]

84. Walker, F.O. Huntington's disease. Lancet 2007, 369, 218-228. [CrossRef]

85. Li, C.; Gotz, J. Tau-based therapies in neurodegeneration: Opportunities and challenges. Nat. Rev. Drug Discov. 2017, 16, 863-883. [CrossRef] [PubMed]

86. Goldman, S.A. Stem and Progenitor Cell-Based Therapy of the Central Nervous System: Hopes, Hype, and Wishful Thinking. Cell Stem Cell 2016, 18, 174-188. [CrossRef] [PubMed]

87. Miao, L.; Yang, L.; Huang, H.; Liang, F.; Ling, C.; Hu, Y. mTORC1 is necessary but mTORC2 and GSK3beta are inhibitory for AKT3-induced axon regeneration in the central nervous system. Elife 2016, 5, e14908. [CrossRef]

88. Kadoya, K.; Tsukada, S.; Lu, P.; Coppola, G.; Geschwind, D.; Filbin, M.T.; Blesch, A.; Tuszynski, M.H. Combined intrinsic and extrinsic neuronal mechanisms facilitate bridging axonal regeneration one year after spinal cord injury. Neuron 2009, 64, 165-172. [CrossRef]

89. Silver, J.; Schwab, M.E.; Popovich, P.G. Central nervous system regenerative failure: Role of oligodendrocytes, astrocytes, and microglia. Cold Spring Harb. Perspect. Biol. 2014, 7, a020602. [CrossRef] [PubMed]

90. Yiu, G.; He, Z. Glial inhibition of CNS axon regeneration. Nat. Rev. Neurosci. 2006, 7, 617-627. [CrossRef]

91. Silver, J.; Miller, J.H. Regeneration beyond the glial scar. Nat. Rev. Neurosci. 2004, 5, 146-156. [CrossRef] [PubMed]

92. Sun, F.; He, Z. Neuronal intrinsic barriers for axon regeneration in the adult CNS. Curr. Opin. Neurobiol. 2010, 20, 510-518. [CrossRef] [PubMed]

93. Park, K.K.; Hu, Y.; Muhling, J.; Pollett, M.A.; Dallimore, E.J.; Turnley, A.M.; Cui, Q.; Harvey, A.R. Cytokine-induced SOCS expression is inhibited by cAMP analogue: Impact on regeneration in injured retina. Mol. Cell Neurosci. 2009, 41, 313-324. [CrossRef] [PubMed]

94. Zhong, J.; Zou, H. BMP signaling in axon regeneration. Curr. Opin. Neurobiol. 2014, 27, 127-134. [CrossRef] [PubMed]

95. Li, C.; Hisamoto, N.; Nix, P.; Kanao, S.; Mizuno, T.; Bastiani, M.; Matsumoto, K. The growth factor SVH-1 regulates axon regeneration in C. elegans via the JNK MAPK cascade. Nat. Neurosci. 2012, 15, 551-557. [CrossRef] [PubMed]

96. Jin, D.; Liu, Y.; Sun, F.; Wang, X.; Liu, X.; He, Z. Restoration of skilled locomotion by sprouting corticospinal axons induced by co-deletion of PTEN and SOCS3. Nat. Commun. 2015, 6, 8074. [CrossRef] [PubMed]

97. Song, Y.; Ori-McKenney, K.M.; Zheng, Y.; Han, C.; Jan, L.Y.; Jan, Y.N. Regeneration of Drosophila sensory neuron axons and dendrites is regulated by the Akt pathway involving Pten and microRNA bantam. Genes Dev. 2012, 26, 1612-1625. [CrossRef] [PubMed]

98. Byrne, A.B.; Walradt, T.; Gardner, K.E.; Hubbert, A.; Reinke, V.; Hammarlund, M. Insulin/IGF1 signaling inhibits age-dependent axon regeneration. Neuron 2014, 81, 561-573. [CrossRef]

99. Li, S.; Yang, C.; Zhang, L.; Gao, X.; Wang, X.; Liu, W.; Wang, Y.; Jiang, S.; Wong, Y.H.; Zhang, Y.; et al. Promoting axon regeneration in the adult CNS by modulation of the melanopsin/GPCR signaling. Proc. Natl. Acad. Sci. USA 2016, 113, 1937-1942. [CrossRef]

100. Lebrun-Julien, F.; Suter, U. Combined HDAC1 and HDAC2 Depletion Promotes Retinal Ganglion Cell Survival After Injury Through Reduction of p53 Target Gene Expression. ASN Neuro 2015, 7, 1759091415593066. [CrossRef]

101. Schmitt, H.M.; Schlamp, C.L.; Nickells, R.W. Targeting HDAC3 Activity with RGFP966 Protects Against Retinal Ganglion Cell Nuclear Atrophy and Apoptosis After Optic Nerve Injury. J. Ocul. Pharmacol. Ther. 2018, 34, 260-273. [CrossRef]

102. Cho, Y.; Cavalli, V. HDAC5 is a novel injury-regulated tubulin deacetylase controlling axon regeneration. EMBO J. 2012, 31, 3063-3078. [CrossRef]

103. Cho, Y.; Sloutsky, R.; Naegle, K.M.; Cavalli, V. Injury-induced HDAC5 nuclear export is essential for axon regeneration. Cell 2013, 155, 894-908. [CrossRef]

104. Pita-Thomas, W.; Mahar, M.; Joshi, A.; Gan, D.; Cavalli, V. HDAC5 promotes optic nerve regeneration by activating the mTOR pathway. Exp. Neurol. 2019, 317, 271-283. [CrossRef] 
105. Tassew, N.G.; Charish, J.; Shabanzadeh, A.P.; Luga, V.; Harada, H.; Farhani, N.; D'Onofrio, P.; Choi, B.; Ellabban, A.; Nickerson, P.E.B.; et al. Exosomes Mediate Mobilization of Autocrine Wnt10b to Promote Axonal Regeneration in the Injured CNS. Cell Rep. 2017, 20, 99-111. [CrossRef]

106. Leibinger, M.; Andreadaki, A.; Fischer, D. Role of mTOR in neuroprotection and axon regeneration after inflammatory stimulation. Neurobiol. Dis. 2012, 46, 314-324. [CrossRef]

107. Lim, J.-H.A.; Stafford, B.K.; Nguyen, P.L.; Lien, B.V.; Wang, C.; Zukor, K.; He, Z.; Huberman, A.D. Neural activity promotes long-distance, target-specific regeneration of adult retinal axons. Nat. Neurosci. 2016, 19, 1073-1084. [CrossRef]

108. Sun, F.; Park, K.K.; Belin, S.; Wang, D.; Lu, T.; Chen, G.; Zhang, K.; Yeung, C.; Feng, G.; Yankner, B.A.; et al. Sustained axon regeneration induced by co-deletion of PTEN and SOCS3. Nature 2011, 480, 372-375. [CrossRef]

109. de Lima, S.; Koriyama, Y.; Kurimoto, T.; Oliveira, J.T.; Yin, Y.; Li, Y.; Gilbert, H.Y.; Fagiolini, M.; Martinez, A.M.; Benowitz, L. Full-length axon regeneration in the adult mouse optic nerve and partial recovery of simple visual behaviors. Proc. Natl. Acad. Sci. USA 2012, 109, 9149-9154. [CrossRef]

110. Pernet, V.; Schwab, M.E. Lost in the jungle: New hurdles for optic nerve axon regeneration. Trends Neurosci. 2014, 37, 381-387. [CrossRef]

111. Li, N.; Wang, F.; Zhang, Q.; Jin, M.; Lu, Y.; Chen, S.; Guo, C.; Zhang, X. Rapamycin mediates mTOR signaling in reactive astrocytes and reduces retinal ganglion cell loss. Exp. Eye Res. 2018, 176, 10-19. [CrossRef]

112. Ahuja, C.S.; Wilson, J.R.; Nori, S.; Kotter, M.R.N.; Druschel, C.; Curt, A.; Fehlings, M.G. Traumatic spinal cord injury. Nat. Rev. Dis. Prim. 2017, 3, 17018. [CrossRef]

113. Codeluppi, S.; Svensson, C.I.; Hefferan, M.P.; Valencia, F.; Silldorff, M.D.; Oshiro, M.; Marsala, M.; Pasquale, E.B. The Rheb-mTOR pathway is upregulated in reactive astrocytes of the injured spinal cord. J. Neurosci. 2009, 29, 1093-1104. [CrossRef]

114. Kanno, H.; Ozawa, H.; Sekiguchi, A.; Yamaya, S.; Tateda, S.; Yahata, K.; Itoi, E. The role of mTOR signaling pathway in spinal cord injury. Cell Cycle 2012, 11, 3175-3179. [CrossRef]

115. Chen, C.-H.; Sung, C.-S.; Huang, S.-Y.; Feng, C.-W.; Hung, H.-C.; Yang, S.-N.; Chen, N.-F.; Tai, M.-H.; Wen, Z.-H.; Chen, W.-F. The role of the PI3K/Akt/mTOR pathway in glial scar formation following spinal cord injury. Exp. Neurol. 2016, 278, 27-41. [CrossRef]

116. Luan, Y.; Chen, M.; Zhou, L. MiR-17 targets PTEN and facilitates glial scar formation after spinal cord injuries via the PI3K/Akt/mTOR pathway. Brain Res. Bull. 2017, 128, 68-75. [CrossRef]

117. Liu, K.; Lu, Y.; Lee, J.K.; Samara, R.; Willenberg, R.; Sears-Kraxberger, I.; Tedeschi, A.; Park, K.K.; Jin, D.; Cai, B.; et al. PTEN deletion enhances the regenerative ability of adult corticospinal neurons. Nat. Neurosci. 2010, 13, 1075-1081. [CrossRef]

118. Al-Ali, H.; Ding, Y.; Slepak, T.; Wu, W.; Sun, Y.; Martinez, Y.; Xu, X.M.; Lemmon, V.P.; Bixby, J.L. The mTOR Substrate S6 Kinase 1 (S6K1) Is a Negative Regulator of Axon Regeneration and a Potential Drug Target for Central Nervous System Injury. J. Neurosci. 2017, 37, 7079-7095. [CrossRef]

119. Du, K.; Zheng, S.; Zhang, Q.; Li, S.; Gao, X.; Wang, J.; Jiang, L.; Liu, K. Pten Deletion Promotes Regrowth of Corticospinal Tract Axons 1 Year after Spinal Cord Injury. J. Neurosci. 2015, 35, 9754-9763. [CrossRef]

120. Yang, P.; Wen, H.; Ou, S.; Cui, J.; Fan, D. IL-6 promotes regeneration and functional recovery after cortical spinal tract injury by reactivating intrinsic growth program of neurons and enhancing synapse formation. Exp. Neurol. 2012, 236, 19-27. [CrossRef]

121. Huang, Z.; Gao, Y.; Sun, Y.; Zhang, C.; Yin, Y.; Shimoda, Y.; Watanabe, K.; Liu, Y. NB-3 signaling mediates the cross-talk between post-traumatic spinal axons and scar-forming cells. EMBO J. 2016, 35, 1745-1765. [CrossRef]

122. Park, K.K.; Liu, K.; Hu, Y.; Kanter, J.L.; He, Z. PTEN/mTOR and axon regeneration. Exp. Neurol. 2010, 223, 45-50. [CrossRef]

123. Abe, N.; Borson, S.H.; Gambello, M.J.; Wang, F.; Cavalli, V. Mammalian target of rapamycin (mTOR) activation increases axonal growth capacity of injured peripheral nerves. J. Biol. Chem. 2010, 285, 28034-28043. [CrossRef]

124. Chen, W.; Lu, N.; Ding, Y.; Wang, Y.; Chan, L.T.; Wang, X.; Gao, X.; Jiang, S.; Liu, K. Rapamycin-Resistant mTOR Activity Is Required for Sensory Axon Regeneration Induced by a Conditioning Lesion. eNeuro 2016, 3, ENEURO.0358-16.2016. [CrossRef] 
125. Thomson, S.E.; Charalambous, C.; Smith, C.A.; Tsimbouri, P.M.; Dejardin, T.; Kingham, P.J.; Hart, A.M.; Riehle, M.O. Microtopographical cues promote peripheral nerve regeneration via transient mTORC2 activation. Acta Biomater. 2017, 60, 220-231. [CrossRef]

126. Liu, Y.; Kelamangalath, L.; Kim, H.; Han, S.B.; Tang, X.; Zhai, J.; Hong, J.W.; Lin, S.; Son, Y.J.; Smith, G.M. NT-3 promotes proprioceptive axon regeneration when combined with activation of the mTor intrinsic growth pathway but not with reduction of myelin extrinsic inhibitors. Exp. Neurol. 2016, 283, 73-84. [CrossRef]

127. Baghdadi, M.B.; Tajbakhsh, S. Regulation and phylogeny of skeletal muscle regeneration. Dev. Biol. 2018, 433, 200-209. [CrossRef]

128. Hawke, T.J.; Garry, D.J. Myogenic satellite cells: Physiology to molecular biology. J. Appl. Physiol. 2001, 91, 534-551. [CrossRef]

129. Mauro, A. Satellite cell of skeletal muscle fibers. J. Biophys. Biochem. Cytol. 1961, 9, 493-495. [CrossRef]

130. Thomson, D.M. The Role of AMPK in the Regulation of Skeletal Muscle Size, Hypertrophy, and Regeneration. Int. J. Mol. Sci. 2018, 19, 3125. [CrossRef]

131. Kuang, S.; Rudnicki, M.A. The emerging biology of satellite cells and their therapeutic potential. Trends Mol. Med. 2008, 14, 82-91. [CrossRef]

132. Charge, S.B.; Rudnicki, M.A. Cellular and molecular regulation of muscle regeneration. Physiol. Rev. 2004, 84, 209-238. [CrossRef]

133. Zhang, P.; Liang, X.; Shan, T.; Jiang, Q.; Deng, C.; Zheng, R.; Kuang, S. mTOR is necessary for proper satellite cell activity and skeletal muscle regeneration. Biochem. Biophys. Res. Commun. 2015, 463, 102-108. [CrossRef]

134. Ge, Y.; Wu, A.L.; Warnes, C.; Liu, J.; Zhang, C.; Kawasome, H.; Terada, N.; Boppart, M.D.; Schoenherr, C.J.; Chen, J. mTOR regulates skeletal muscle regeneration in vivo through kinase-dependent and kinase-independent mechanisms. Am. J. Physiol. Cell Physiol. 2009, 297, C1434-C1444. [CrossRef]

135. Lepper, C.; Conway, S.J.; Fan, C.M. Adult satellite cells and embryonic muscle progenitors have distinct genetic requirements. Nature 2009, 460, 627-631. [CrossRef]

136. Rion, N.; Castets, P.; Lin, S.; Enderle, L.; Reinhard, J.R.; Eickhorst, C.; Ruegg, M.A. mTOR controls embryonic and adult myogenesis via mTORC1. Development 2019, 146, dev172460. [CrossRef]

137. Jash, S.; Dhar, G.; Ghosh, U.; Adhya, S. Role of the mTORC1 complex in satellite cell activation by RNA-induced mitochondrial restoration: Dual control of cyclin D1 through microRNAs. Mol. Cell Biol. 2014, 34, 3594-3606. [CrossRef]

138. Kikani, C.K.; Wu, X.; Fogarty, S.; Kang, S.A.W.; Dephoure, N.; Gygi, S.P.; Sabatini, D.M.; Rutter, J. Activation of PASK by mTORC1 is required for the onset of the terminal differentiation program. Proc. Natl. Acad. Sci. USA 2019, 116, 10382-10391. [CrossRef]

139. Greco, S.; De Simone, M.; Colussi, C.; Zaccagnini, G.; Fasanaro, P.; Pescatori, M.; Cardani, R.; Perbellini, R.; Isaia, E.; Sale, P.; et al. Common micro-RNA signature in skeletal muscle damage and regeneration induced by Duchenne muscular dystrophy and acute ischemia. FASEB J. 2009, 23, 3335-3346. [CrossRef]

140. Yuasa, K.; Hagiwara, Y.; Ando, M.; Nakamura, A.; Takeda, S.I.; Hijikata, T. MicroRNA-206 is highly expressed in newly formed muscle fibers implications regarding potential for muscle regeneration and maturation in muscular dystrophy.pdf. Cell Struct. Funct. 2008, 33, 163-169. [CrossRef]

141. Sun, Y.; Ge, Y.; Drnevich, J.; Zhao, Y.; Band, M.; Chen, J. Mammalian target of rapamycin regulates miRNA-1 and follistatin in skeletal myogenesis. J. Cell Biol. 2010, 189, 1157-1169. [CrossRef]

142. Ge, Y.; Sun, Y.; Chen, J. IGF-II is regulated by microRNA-125b in skeletal myogenesis. J. Cell Biol. 2011, 192, 69-81. [CrossRef]

143. Matsumoto, A.; Pasut, A.; Matsumoto, M.; Yamashita, R.; Fung, J.; Monteleone, E.; Saghatelian, A.; Nakayama, K.I.; Clohessy, J.G.; Pandolfi, P.P. mTORC1 and muscle regeneration are regulated by the LINC00961-encoded SPAR polypeptide. Nature 2017, 541, 228-232. [CrossRef]

144. Hung, C.M.; Calejman, C.M.; Sanchez-Gurmaches, J.; Li, H.; Clish, C.B.; Hettmer, S.; Wagers, A.J.; Guertin, D.A. Rictor/mTORC2 loss in the Myf5 lineage reprograms brown fat metabolism and protects mice against obesity and metabolic disease. Cell Rep. 2014, 8, 256-271. [CrossRef]

145. Sadtler, K.; Estrellas, K.; Allen, B.W.; Wolf, M.T.; Fan, H.; Tam, A.J.; Patel, C.H.; Luber, B.S.; Wang, H.; Wagner, K.R.; et al. Developing a pro-regenerative biomaterial scaffold microenvironment requires $\mathrm{T}$ helper 2 cells. Science 2016, 352, 366-370. [CrossRef] 
146. Zanou, N.; Schakman, O.; Louis, P.; Ruegg, U.T.; Dietrich, A.; Birnbaumer, L.; Gailly, P. Trpc1 ion channel modulates phosphatidylinositol 3-kinase/Akt pathway during myoblast differentiation and muscle regeneration. J. Biol. Chem. 2012, 287, 14524-14534. [CrossRef]

147. Zeng, Q.; Fu, Q.; Wang, X.; Zhao, Y.; Liu, H.; Li, Z.; Li, F. Protective Effects of Sonic Hedgehog Against Ischemia/Reperfusion Injury in Mouse Skeletal Muscle via AKT/mTOR/p70S6K Signaling. Cell. Physiol. Biochem. Int. J. Exp. Cell. Physiol. Biochem. Pharmacol. 2017, 43, 1813-1828. [CrossRef]

148. Sharples, A.P.; Hughes, D.C.; Deane, C.S.; Saini, A.; Selman, C.; Stewart, C.E. Longevity and skeletal muscle mass: The role of IGF signalling, the sirtuins, dietary restriction and protein intake. Aging Cell 2015, 14, 511-523. [CrossRef]

149. Erbay, E.; Park, I.H.; Nuzzi, P.D.; Schoenherr, C.J.; Chen, J. IGF-II transcription in skeletal myogenesis is controlled by mTOR and nutrients. J. Cell Biol. 2003, 163, 931-936. [CrossRef]

150. Pratiwi, Y.S.; Lesmana, R.; Goenawan, H.; Sylviana, N.; Setiawan, I.; Tarawan, V.M.; Lestari, K.; Abdulah, R.; Dwipa, L.; Purba, A.; et al. Nutmeg Extract Increases Skeletal Muscle Mass in Aging Rats Partly via IGF1-AKT-mTOR Pathway and Inhibition of Autophagy. Evid.-Based Complement. Altern. Med. eCAM 2018, 2018, 2810840. [CrossRef]

151. Frontera, W.R.; Hughes, V.A.; Fielding, R.A.; Fiatarone, M.A.; Evans, W.J.; Roubenoff, R. Aging of skeletal muscle: A 12-yr longitudinal study. J. Appl. Physiol. 2000, 88, 1321-1326. [CrossRef]

152. Zacharewicz, E.; Della Gatta, P.; Reynolds, J.; Garnham, A.; Crowley, T.; Russell, A.P.; Lamon, S. Identification of microRNAs linked to regulators of muscle protein synthesis and regeneration in young and old skeletal muscle. PLoS ONE 2014, 9, e114009. [CrossRef]

153. Conboy, I.M.; Conboy, M.J.; Smythe, G.M.; Rando, T.A. Notch-mediated restoration of regenerative potential to aged muscle. Science 2003, 302, 1575-1577. [CrossRef]

154. Shavlakadze, T.; McGeachie, J.; Grounds, M.D. Delayed but excellent myogenic stem cell response of regenerating geriatric skeletal muscles in mice. Biogerontology 2010, 11, 363-376. [CrossRef]

155. Pereira, M.G.; Silva, M.T.; da Cunha, F.M.; Moriscot, A.S.; Aoki, M.S.; Miyabara, E.H. Leucine supplementation improves regeneration of skeletal muscles from old rats. Exp. Gerontol. 2015, 72, 269-277. [CrossRef]

156. Perry, R.A., Jr.; Brown, L.A.; Lee, D.E.; Brown, J.L.; Baum, J.I.; Greene, N.P.; Washington, T.A. Differential effects of leucine supplementation in young and aged mice at the onset of skeletal muscle regeneration. Mech. Ageing Dev. 2016, 157, 7-16. [CrossRef]

157. Pereira, M.G.; Baptista, I.L.; Carlassara, E.O.; Moriscot, A.S.; Aoki, M.S.; Miyabara, E.H. Leucine supplementation improves skeletal muscle regeneration after cryolesion in rats. PLoS ONE 2014, 9, e85283. [CrossRef]

158. Perry, R.A., Jr.; Brown, L.A.; Lee, D.E.; Brown, J.L.; Baum, J.I.; Greene, N.P.; Washington, T.A. The Akt/mTOR pathway: Data comparing young and aged mice with leucine supplementation at the onset of skeletal muscle regeneration. Data Brief 2016, 8, 1426-1432. [CrossRef]

159. Mouisel, E.; Vignaud, A.; Hourde, C.; Butler-Browne, G.; Ferry, A. Muscle weakness and atrophy are associated with decreased regenerative capacity and changes in mTOR signaling in skeletal muscles of venerable (18-24-month-old) dystrophic mdx mice. Muscle Nerve 2010, 41, 809-818. [CrossRef]

160. Jones, D.L.; Rando, T.A. Emerging models and paradigms for stem cell ageing. Nat. Cell Biol. 2011, 13, 506-512. [CrossRef]

161. Chandel, N.S.; Jasper, H.; Ho, T.T.; Passegue, E. Metabolic regulation of stem cell function in tissue homeostasis and organismal ageing. Nat. Cell Biol. 2016, 18, 823-832. [CrossRef]

162. Haller, S.; Kapuria, S.; Riley, R.R.; O’Leary, M.N.; Schreiber, K.H.; Andersen, J.K.; Melov, S.; Que, J.; Rando, T.A.; Rock, J.; et al. mTORC1 Activation during Repeated Regeneration Impairs Somatic Stem Cell Maintenance. Cell Stem Cell 2017, 21, 806-818. [CrossRef]

163. Su, Z.; Robinson, A.; Hu, L.; Klein, J.D.; Hassounah, F.; Li, M.; Wang, H.; Cai, H.; Wang, X.H. Acupuncture plus Low-Frequency Electrical Stimulation (Acu-LFES) Attenuates Diabetic Myopathy by Enhancing Muscle Regeneration. PLoS ONE 2015, 10, e0134511. [CrossRef]

164. Chaillou, T.; Koulmann, N.; Meunier, A.; Pugniere, P.; McCarthy, J.J.; Beaudry, M.; Bigard, X. Ambient hypoxia enhances the loss of muscle mass after extensive injury. Pflug. Archiv Eur. J. Physiol. 2014, 466, 587-598. [CrossRef] 
165. Favier, F.B.; Costes, F.; Defour, A.; Bonnefoy, R.; Lefai, E.; Bauge, S.; Peinnequin, A.; Benoit, H.; Freyssenet, D. Downregulation of Akt/mammalian target of rapamycin pathway in skeletal muscle is associated with increased REDD1 expression in response to chronic hypoxia. Am. J. Physiol. Regul. Integr. Comp. Physiol. 2010, 298, R1659-R1666. [CrossRef]

166. Cohen, S.; Nathan, J.A.; Goldberg, A.L. Muscle wasting in disease: Molecular mechanisms and promising therapies. Nat. Rev. Drug Discov. 2015, 14, 58-74. [CrossRef]

167. Miyajima, A.; Tanaka, M.; Itoh, T. Stem/progenitor cells in liver development, homeostasis, regeneration, and reprogramming. Cell Stem Cell 2014, 14, 561-574. [CrossRef]

168. Mao, S.A.; Glorioso, J.M.; Nyberg, S.L. Liver regeneration. Transl. Res. 2014, 163, 352-362. [CrossRef]

169. Michalopoulos, G.K.; DeFrances, M.C. Liver regeneration. Science 1997, 276, 60-66. [CrossRef]

170. Greene, A.K.; Puder, M. Partial hepatectomy in the mouse: Technique and perioperative management. J. Investig. Surg. 2003, 16, 99-102. [CrossRef]

171. Bohm, F.; Kohler, U.A.; Speicher, T.; Werner, S. Regulation of liver regeneration by growth factors and cytokines. EMBO Mol. Med. 2010, 2, 294-305. [CrossRef]

172. Yanger, K.; Knigin, D.; Zong, Y.; Maggs, L.; Gu, G.; Akiyama, H.; Pikarsky, E.; Stanger, B.Z. Adult hepatocytes are generated by self-duplication rather than stem cell differentiation. Cell Stem Cell 2014, 15, 340-349. [CrossRef]

173. Itoh, T.; Miyajima, A. Liver regeneration by stem/progenitor cells. Hepatology 2014, 59, 1617-1626. [CrossRef]

174. He, J.; Lu, H.; Zou, Q.; Luo, L. Regeneration of liver after extreme hepatocyte loss occurs mainly via biliary transdifferentiation in zebrafish. Gastroenterology 2014, 146, 789-800. [CrossRef]

175. Choi, T.Y.; Ninov, N.; Stainier, D.Y.; Shin, D. Extensive conversion of hepatic biliary epithelial cells to hepatocytes after near total loss of hepatocytes in zebrafish. Gastroenterology 2014, 146, 776-788. [CrossRef]

176. Raven, A.; Lu, W.Y.; Man, T.Y.; Ferreira-Gonzalez, S.; O’Duibhir, E.; Dwyer, B.J.; Thomson, J.P.; Meehan, R.R.; Bogorad, R.; Koteliansky, V.; et al. Cholangiocytes act as facultative liver stem cells during impaired hepatocyte regeneration. Nature 2017, 547, 350-354. [CrossRef]

177. Deng, X.; Zhang, X.; Li, W.; Feng, R.X.; Li, L.; Yi, G.R.; Zhang, X.N.; Yin, C.; Yu, H.Y.; Zhang, J.P.; et al. Chronic Liver Injury Induces Conversion of Biliary Epithelial Cells into Hepatocytes. Cell Stem Cell 2018, 23, 114-122. [CrossRef]

178. Panasyuk, G.; Patitucci, C.; Espeillac, C.; Pende, M. The role of the mTOR pathway during liver regeneration and tumorigenesis. Ann. D'endocrinologie 2013, 74, 121-122. [CrossRef]

179. He, J.; Chen, J.; Wei, X.; Leng, H.; Mu, H.; Cai, P.; Luo, L. mTORC1 Signaling is Required for the Dedifferentiation from Biliary Cell to Bi-potential Progenitor Cell in Zebrafish Liver Regeneration. Hepatology 2019. [CrossRef]

180. Fujiyoshi, M.; Ozaki, M. Molecular mechanisms of liver regeneration and protection for treatment of liver dysfunction and diseases. J. Hepato-Biliary-Pancreat. Sci. 2011, 18, 13-22. [CrossRef]

181. Haga, S.; Ozaki, M.; Inoue, H.; Okamoto, Y.; Ogawa, W.; Takeda, K.; Akira, S.; Todo, S. The survival pathways phosphatidylinositol-3 kinase (PI3-K)/phosphoinositide-dependent protein kinase 1 (PDK1)/Akt modulate liver regeneration through hepatocyte size rather than proliferation. Hepatology 2009, 49, 204-214. [CrossRef]

182. Fouraschen, S.M.; de Ruiter, P.E.; Kwekkeboom, J.; de Bruin, R.W.; Kazemier, G.; Metselaar, H.J.; Tilanus, H.W.; van der Laan, L.J.; de Jonge, J. mTOR signaling in liver regeneration: Rapamycin combined with growth factor treatment. World J. Transplant. 2013, 3, 36-47. [CrossRef]

183. Kwon, H.J.; Won, Y.S.; Yoon, Y.D.; Yoon, W.K.; Nam, K.H.; Choi, I.P.; Kim, D.Y.; Kim, H.C. Vitamin D3 up-regulated protein 1 deficiency accelerates liver regeneration after partial hepatectomy in mice. J. Hepatol. 2011, 54, 1168-1176. [CrossRef]

184. Chen, P.; Yan, H.; Chen, Y.; He, Z. The variation of AkT/TSC1-TSC1/mTOR signal pathway in hepatocytes after partial hepatectomy in rats. Exp. Mol. Pathol. 2009, 86, 101-107. [CrossRef]

185. Rickheim, D.G.; Nelsen, C.J.; Fassett, J.T.; Timchenko, N.A.; Hansen, L.K.; Albrecht, J.H. Differential regulation of cyclins D1 and D3 in hepatocyte proliferation. Hepatology 2002, 36, 30-38. [CrossRef]

186. Espeillac, C.; Mitchell, C.; Celton-Morizur, S.; Chauvin, C.; Koka, V.; Gillet, C.; Albrecht, J.H.; Desdouets, C.; Pende, M. S6 kinase 1 is required for rapamycin-sensitive liver proliferation after mouse hepatectomy. J. Clin. Investig. 2011, 121, 2821-2832. [CrossRef]

187. Jiang, Y.-P.; Ballou, L.M.; Lin, R.Z. Rapamycin-insensitive Regulation of 4E-BP1 in Regenerating Rat Liver. J. Biol. Chem. 2001, 276, 10943-10951. [CrossRef] 
188. Palmes, D.; Zibert, A.; Budny, T.; Bahde, R.; Minin, E.; Kebschull, L.; Holzen, J.; Schmidt, H.; Spiegel, H.U. Impact of rapamycin on liver regeneration. Virchows Arch. 2008, 452, 545-557. [CrossRef]

189. Matot, I.; Nachmansson, N.; Duev, O.; Schulz, S.; Schroeder-Stein, K.; Frede, S.; Abramovitch, R. Impaired liver regeneration after hepatectomy and bleeding is associated with a shift from hepatocyte proliferation to hypertrophy. FASEB J. 2017, 31, 5283-5295. [CrossRef]

190. Ng, R.; Song, G.; Roll, G.R.; Frandsen, N.M.; Willenbring, H. A microRNA-21 surge facilitates rapid cyclin D1 translation and cell cycle progression in mouse liver regeneration. J. Clin. Investig. 2012, 122, 1097-1108. [CrossRef]

191. Liu, Q.; Pu, S.; Chen, L.; Shen, J.; Cheng, S.; Kuang, J.; Li, H.; Wu, T.; Li, R.; Jiang, W.; et al. Liver-specific Sirtuin6 ablation impairs liver regeneration after 2/3 partial hepatectomy. Wound Repair Regen. 2019, 27, 366-374. [CrossRef]

192. Garcia-Rodriguez, J.L.; Barbier-Torres, L.; Fernandez-Alvarez, S.; Gutierrez-de Juan, V.; Monte, M.J.; Halilbasic, E.; Herranz, D.; Alvarez, L.; Aspichueta, P.; Marin, J.J.; et al. SIRT1 controls liver regeneration by regulating bile acid metabolism through farnesoid $\mathrm{X}$ receptor and mammalian target of rapamycin signaling. Hepatology 2014, 59, 1972-1983. [CrossRef]

193. Shi, H.; Zhang, Y.; Ji, J.; Xu, P.; Shi, H.; Yue, X.; Ren, F.; Chen, Y.; Duan, Z.; Chen, D. Deficiency of apoptosis-stimulating protein two of p53 promotes liver regeneration in mice by activating mammalian target of rapamycin. Sci. Rep. 2018, 8, 17927. [CrossRef]

194. Wu, L.; Nguyen, L.H.; Zhou, K.; de Soysa, T.Y.; Li, L.; Miller, J.B.; Tian, J.; Locker, J.; Zhang, S.; Shinoda, G.; et al. Precise let-7 expression levels balance organ regeneration against tumor suppression. Elife 2015, 4, e09431. [CrossRef]

195. Lou, K.; Yang, M.; Duan, E.; Zhao, J.; Yu, C.; Zhang, R.; Zhang, L.; Zhang, M.; Xiao, Z.; Hu, W.; et al. Rosmarinic acid stimulates liver regeneration through the mTOR pathway. Phytomedicine 2016, 23, 1574-1582. [CrossRef]

196. Kawaguchi, T.; Kodama, T.; Hikita, H.; Tanaka, S.; Shigekawa, M.; Nawa, T.; Shimizu, S.; Li, W.; Miyagi, T.; Hiramatsu, N.; et al. Carbamazepine promotes liver regeneration and survival in mice. J. Hepatol. 2013, 59, 1239-1245. [CrossRef]

197. Zhong, H.; Wu, H.; Bai, H.; Wang, M.; Wen, J.; Gong, J.; Miao, M.; Yuan, F. Panax notoginseng saponins promote liver regeneration through activation of the PI3K/AKT/mTOR cell proliferation pathway and upregulation of the AKT/Bad cell survival pathway in mice. BMC Complement. Altern Med. 2019, 19, 122. [CrossRef]

198. Zhang, D.X.; Li, C.H.; Zhang, A.Q.; Jiang, S.; Lai, Y.H.; Ge, X.L.; Pan, K.; Dong, J.H. mTOR-Dependent Suppression of Remnant Liver Regeneration in Liver Failure After Massive Liver Resection in Rats. Dig. Dis. Sci. 2015, 60, 2718-2729. [CrossRef]

199. Haga, S.; Ogawa, W.; Inoue, H.; Terui, K.; Ogino, T.; Igarashi, R.; Takeda, K.; Akira, S.; Enosawa, S.; Furukawa, H.; et al. Compensatory recovery of liver mass by Akt-mediated hepatocellular hypertrophy in liver-specific STAT3-deficient mice. J. Hepatol. 2005, 43, 799-807. [CrossRef]

200. Planas-Paz, L.; Sun, T.; Pikiolek, M.; Cochran, N.R.; Bergling, S.; Orsini, V.; Yang, Z.; Sigoillot, F.; Jetzer, J.; Syed, M.; et al. YAP, but Not RSPO-LGR4/5, Signaling in Biliary Epithelial Cells Promotes a Ductular Reaction in Response to Liver Injury. Cell Stem Cell 2019, 25, 39-53. [CrossRef]

201. Chaturantabut, S.; Shwartz, A.; Evason, K.J.; Cox, A.G.; Labella, K.; Schepers, A.G.; Yang, S.; Acuna, M.; Houvras, Y.; Mancio-Silva, L.; et al. Estrogen Activation of G-Protein-Coupled Estrogen Receptor 1 Regulates Phosphoinositide 3-Kinase and mTOR Signaling to Promote Liver Growth in Zebrafish and Proliferation of Human Hepatocytes. Gastroenterology 2019, 156, 1788-1804. [CrossRef]

202. Fausto, N. Liver regeneration: From laboratory to clinic. Liver Transpl. 2001, 7, 835-844. [CrossRef]

203. Bataller, R.; Brenner, D.A. Liver fibrosis. J. Clin. Investig. 2005, 115, 209-218. [CrossRef]

204. Uribe, M.; Uribe-Echevarria, S.; Mandiola, C.; Zapata, M.I.; Riquelme, F.; Romanque, P. Insight on ALPPS-Associating Liver Partition and Portal Vein Ligation for Staged Hepatectomy-Mechanisms: Activation of mTOR pathway. HPB (Oxf.) 2018, 20, 729-738. [CrossRef]

205. Pan, N.; Lv, X.; Liang, R.; Wang, L.; Liu, Q. Suppression of graft regeneration, not ischemia/reperfusion injury, is the primary cause of small-for-size syndrome after partial liver transplantation in mice. PLoS ONE 2014, 9, e93636. [CrossRef] 
206. Liu, Q.; Rehman, H.; Krishnasamy, Y.; Haque, K.; Schnellmann, R.G.; Lemasters, J.J.; Zhong, Z. Amphiregulin stimulates liver regeneration after small-for-size mouse liver transplantation. Am. J. Transplant. 2012, 12, 2052-2061. [CrossRef]

207. Gehart, H.; Clevers, H. Tales from the crypt: New insights into intestinal stem cells. Nat. Rev. Gastroenterol. Hepatol. 2019, 16, 19-34. [CrossRef]

208. Biteau, B.; Hochmuth, C.E.; Jasper, H. JNK activity in somatic stem cells causes loss of tissue homeostasis in the aging Drosophila gut. Cell Stem Cell 2008, 3, 442-455. [CrossRef]

209. Jiang, H.; Patel, P.H.; Kohlmaier, A.; Grenley, M.O.; McEwen, D.G.; Edgar, B.A. Cytokine/Jak/Stat signaling mediates regeneration and homeostasis in the Drosophila midgut. Cell 2009, 137, 1343-1355. [CrossRef]

210. Amcheslavsky, A.; Ito, N.; Jiang, J.; Ip, Y.T. Tuberous sclerosis complex and Myc coordinate the growth and division of Drosophila intestinal stem cells. J. Cell Biol. 2011, 193, 695-710. [CrossRef]

211. Makky, K.; Tekiela, J.; Mayer, A.N. Target of rapamycin (TOR) signaling controls epithelial morphogenesis in the vertebrate intestine. Dev. Biol. 2007, 303, 501-513. [CrossRef]

212. Metcalfe, C.; Kljavin, N.M.; Ybarra, R.; de Sauvage, F.J. Lgr5+ stem cells are indispensable for radiation-induced intestinal regeneration. Cell Stem Cell 2014, 14, 149-159. [CrossRef]

213. van Es, J.H.; Sato, T.; van de Wetering, M.; Lyubimova, A.; Yee Nee, A.N.; Gregorieff, A.; Sasaki, N.; Zeinstra, L.; van den Born, M.; Korving, J.; et al. Dll1+ secretory progenitor cells revert to stem cells upon crypt damage. Nat. Cell Biol. 2012, 14, 1099-1104. [CrossRef]

214. Tetteh, P.W.; Basak, O.; Farin, H.F.; Wiebrands, K.; Kretzschmar, K.; Begthel, H.; van den Born, M.; Korving, J.; de Sauvage, F.; van Es, J.H.; et al. Replacement of Lost Lgr5-Positive Stem Cells through Plasticity of Their Enterocyte-Lineage Daughters. Cell Stem Cell 2016, 18, 203-213. [CrossRef]

215. Yu, S.; Tong, K.; Zhao, Y.; Balasubramanian, I.; Yap, G.S.; Ferraris, R.P.; Bonder, E.M.; Verzi, M.P.; Gao, N. Paneth Cell Multipotency Induced by Notch Activation following Injury. Cell Stem Cell 2018, 23, 46-59. [CrossRef]

216. Zhou, J.Y.; Huang, D.G.; Qin, Y.C.; Li, X.G.; Gao, C.Q.; Yan, H.C.; Wang, X.Q. mTORC1 signaling activation increases intestinal stem cell activity and promotes epithelial cell proliferation. J. Cell. Physiol. 2019, 234, 19028-19038. [CrossRef]

217. Igarashi, M.; Guarente, L. mTORC1 and SIRT1 Cooperate to Foster Expansion of Gut Adult Stem Cells during Calorie Restriction. Cell 2016, 166, 436-450. [CrossRef]

218. Ashton, G.H.; Morton, J.P.; Myant, K.; Phesse, T.J.; Ridgway, R.A.; Marsh, V.; Wilkins, J.A.; Athineos, D.; Muncan, V.; Kemp, R.; et al. Focal adhesion kinase is required for intestinal regeneration and tumorigenesis downstream of Wnt/c-Myc signaling. Dev. Cell 2010, 19, 259-269. [CrossRef]

219. Nagahama, Y.; Shimoda, M.; Mao, G.; Singh, S.K.; Kozakai, Y.; Sun, X.; Motooka, D.; Nakamura, S.; Tanaka, H.; Satoh, T.; et al. Regnase-1 controls colon epithelial regeneration via regulation of mTOR and purine metabolism. Proc. Natl. Acad. Sci. USA 2018, 115, 11036-11041. [CrossRef]

220. Morton, J.P.; Myant, K.B.; Sansom, O.J. A FAK-PI-3K-mTOR axis is required for Wnt-Myc driven intestinal regeneration and tumorigenesis. Cell Cycle 2014, 10, 173-175. [CrossRef]

221. Faller, W.J.; Jackson, T.J.; Knight, J.R.; Ridgway, R.A.; Jamieson, T.; Karim, S.A.; Jones, C.; Radulescu, S.; Huels, D.J.; Myant, K.B.; et al. mTORC1-mediated translational elongation limits intestinal tumour initiation and growth. Nature 2015, 517, 497-500. [CrossRef]

222. Guan, Y.; Zhang, L.; Li, X.; Zhang, X.; Liu, S.; Gao, N.; Li, L.; Gao, G.; Wei, G.; Chen, Z.; et al. Repression of Mammalian Target of Rapamycin Complex 1 Inhibits Intestinal Regeneration in Acute Inflammatory Bowel Disease Models. J. Immunol. 2015, 195, 339-346. [CrossRef]

223. Perl, A. mTOR-dependent autophagy contributes to end-organ resistance and serves as target for treatment in autoimmune disease. EBioMedicine 2018, 36, 12-13. [CrossRef]

224. Maiese, K.; Chong, Z.Z.; Shang, Y.C.; Wang, S. mTOR: On target for novel therapeutic strategies in the nervous system. Trends Mol. Med. 2013, 19, 51-60. [CrossRef]

225. Laplante, M.; Sabatini, D.M. mTOR signaling in growth control and disease. Cell 2012, 149, $274-293$. [CrossRef]

226. Arroyo, V.; Jalan, R. Acute-on-Chronic Liver Failure: Definition, Diagnosis, and Clinical Characteristics. Semin. Liver Dis. 2016, 36, 109-116. [CrossRef] 
227. Wang, Y.; Newman, M.R.; Ackun-Farmmer, M.; Baranello, M.P.; Sheu, T.-J.; Puzas, J.E.; Benoit, D.S.W. Fracture-Targeted Delivery of $\beta$-Catenin Agonists via Peptide-Functionalized Nanoparticles Augments Fracture Healing. ACS Nano 2017, 11, 9445-9458. [CrossRef]

228. Lai, Z.-W.; Kelly, R.; Winans, T.; Marchena, I.; Shadakshari, A.; Yu, J.; Dawood, M.; Garcia, R.; Tily, H.; Francis, L.; et al. Sirolimus in patients with clinically active systemic lupus erythematosus resistant to, or intolerant of, conventional medications: A single-arm, open-label, phase 1/2 trial. Lancet 2018, 391, 1186-1196. [CrossRef]

(C) 2019 by the authors. Licensee MDPI, Basel, Switzerland. This article is an open access article distributed under the terms and conditions of the Creative Commons Attribution (CC BY) license (http://creativecommons.org/licenses/by/4.0/). 